\title{
THE IMPACT OF "WEST NOUBARIA RURAL DEVELOPMENT" PROJECT ON THE HUMAN AND SOCIAL CAPITALS OF RURAL HOUSEHOLD
}

(Received:14. 12. 2017)

\author{
By \\ M. H. Nawar, S. M. Ismail, H. M. Tohamy" and A. K. Siddique* \\ Rural Sociology and Agricultural Extension Department, Faculty of Agriculture, Cairo University \\ "Social Studies Department, Socio-Economic Studies Division, Desert Research Center
}

\begin{abstract}
The main objectives of the current research were to identify the changes that took place in the rural households' human social capitals as a result of the activities of "West Noubaria Rural Development" project funded by IFAD. Also, to identify the rate of changes. The study was conducted on a sample of 165 respondents from 4 villages (Tiba and Al-Entlaqa in the west of Al- Noubaria) at El-Beheira Governorate who were selected using simple random sampling. Data were collected during the period from February to April 2017, using a questionnaire administrated through personal interviews. The study revealed the following results: 1 . There is a significant difference (at 0.05 ) between human capital before and after the project implementation in favor of post project impact with a relative change in human capital of about $34.68 \%$. 2. There is a significant difference (at 0.05 ) between social capital before and after the implementation of the project in favor of post project impact with a relative change of about $26.22 \%$.
\end{abstract}

Key words: human capitals, social capitals, west Noubaria rural development.
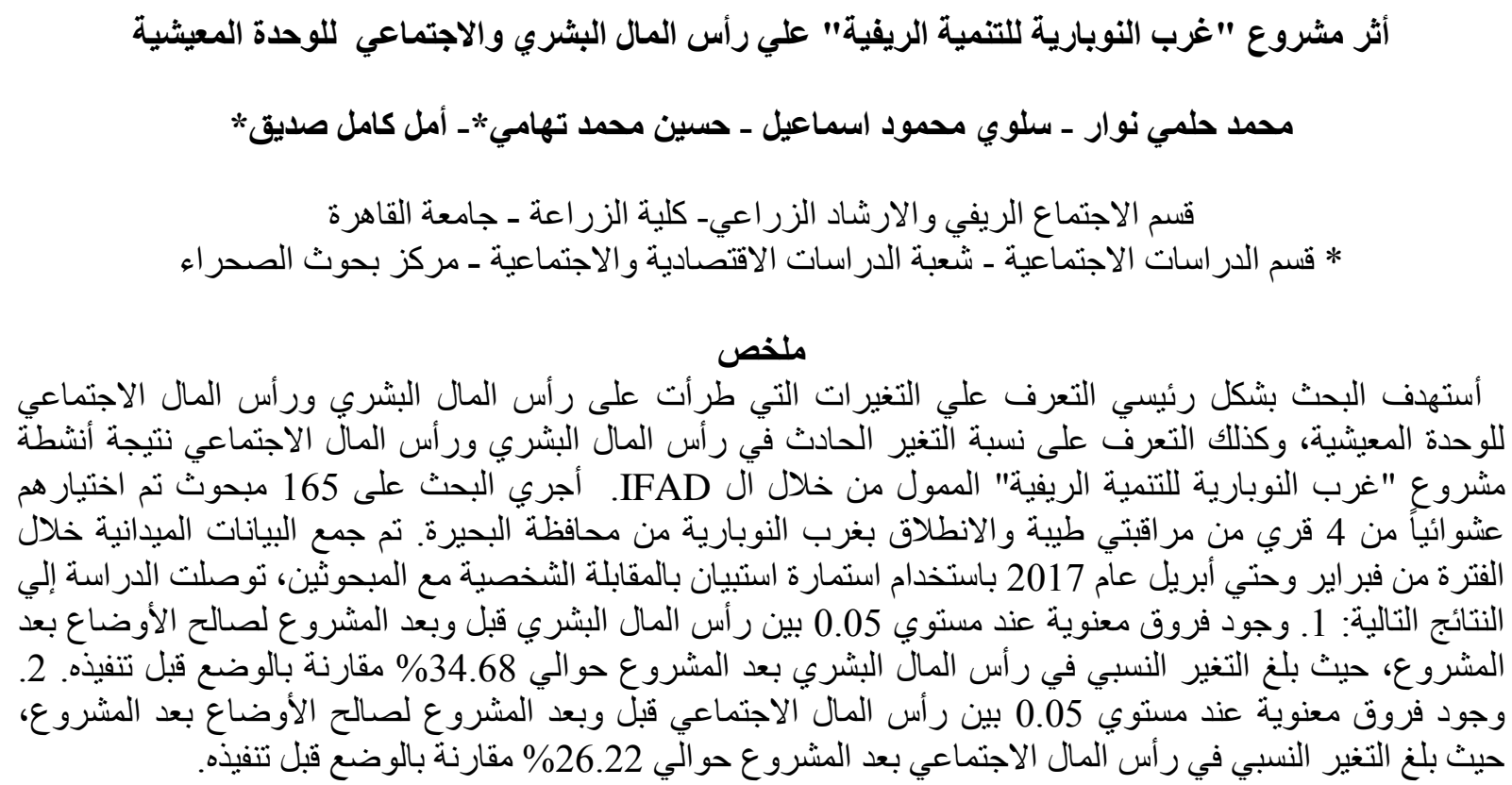

العالمية الثانية. ولقد أكدت المؤسسات الدولية وخبر اء الأمم

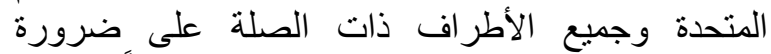
الاهتمام بتنمية الريف في جميع بلدان العالم عموماً و البلدان

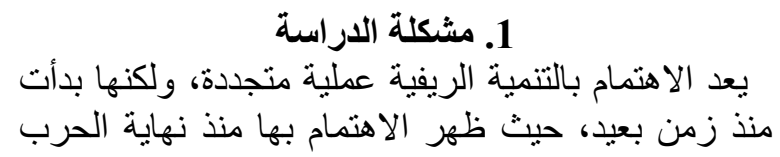

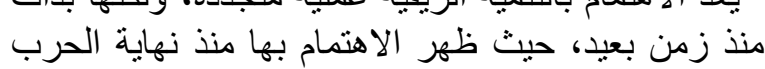




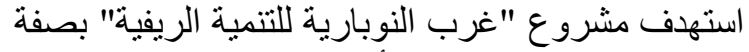

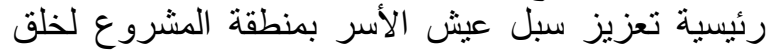

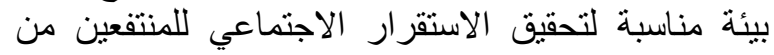
مشروع التوطين وخلق مجتمع متماسك يضم لأل هؤلاء

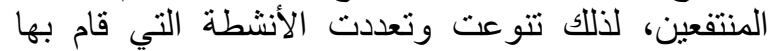

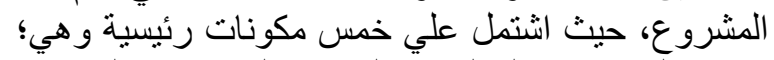

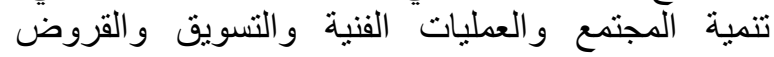

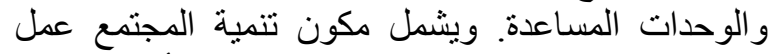

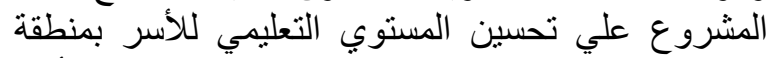

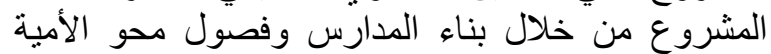

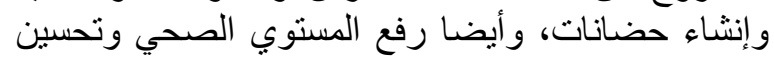

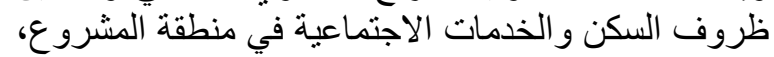

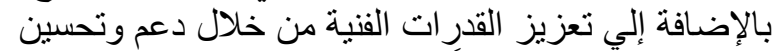

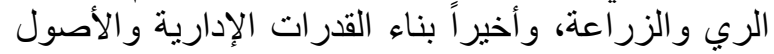

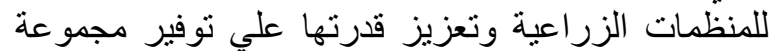
من الخدمات في مجال إدارة المياه والايتتمان وتسويز منتجات أعضائها (IFAD، 2002) وبناءاً علي تنفيذ تلاك الأنشطة فمن المتوقع ظهور العديد

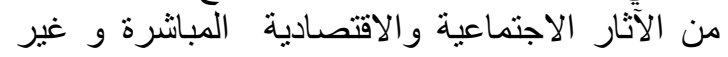

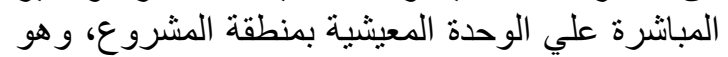

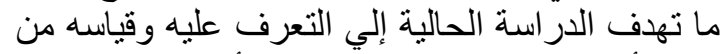

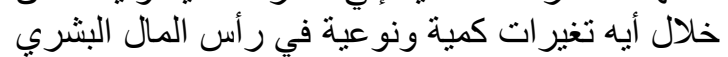

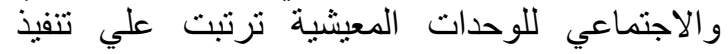
المشروع "غرب النوبارية للتنمية الريفية" الرئية

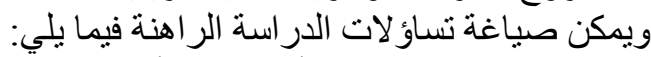

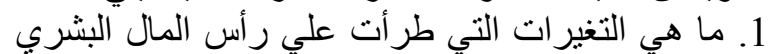

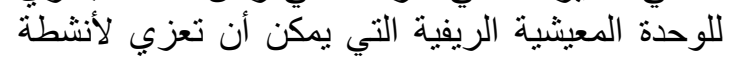
المشروع.

2. ما هي التغيرات التي طرأت علي رأس المال

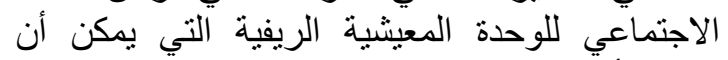
تعزي لأنشطة المشروع.

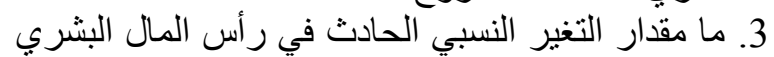
للوحدة المعيشية الريفية التي يمكن أن تعزي لأنشي النشئة

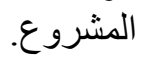

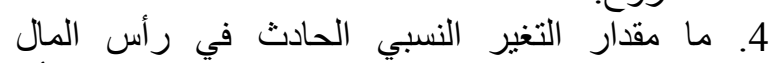
الاجتماعي للوحدة المعيشية الريفية ألتي يمكن أني الني تعزي لأنشّة المشروع.

\section{2. - 2. الإطار النظري}

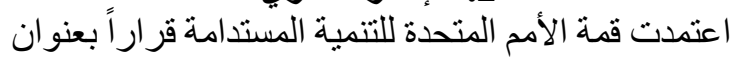
"تحويل عالمنا: جدول أعمال 2030 للتنمية المستدامة المانة يشتمل على 17 هدف للتنمية المستدامة و 169 ألماية

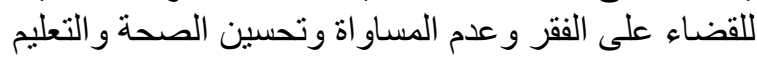

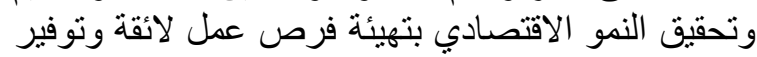

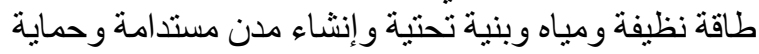

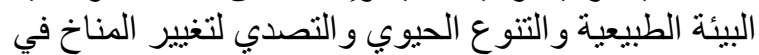
أجو اء تتسم بالسلام و العدل (الأمم المتحدة: 2015).

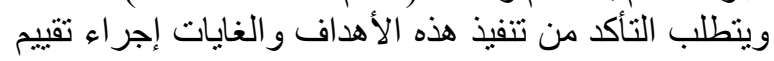

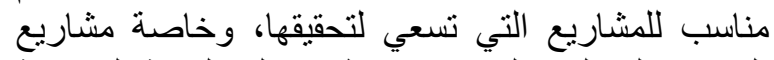
القضاء علي الفقر التي تقوم معظمها علي التنمية الزر اعية
النامية على وجه الخصوص، وذللك في ضو ء ما تعانيه هذه

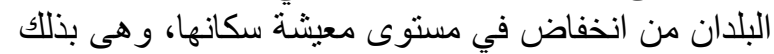

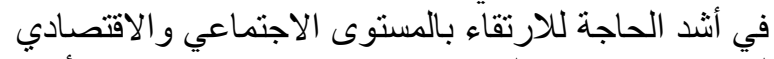

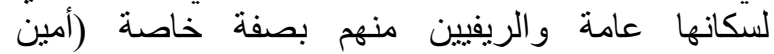

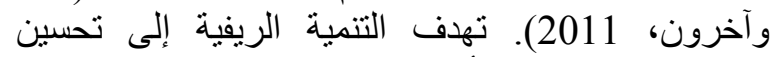

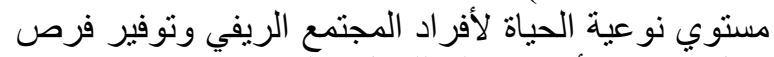

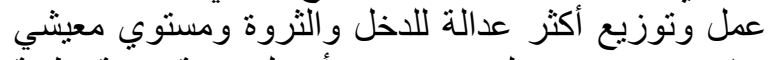
مناسب ومستوي تعليمي وصحي أفضل وبيئة ريفية ريفية نظيفة

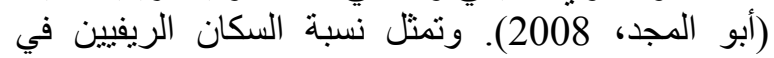
جمهورية مصر العربية نحو 57.8\% من العندة السكان (جهاز

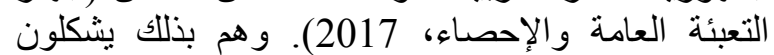
الكتلة السكانية الأكبر التئي يمكن أن تساهم بفاعلية في بأني

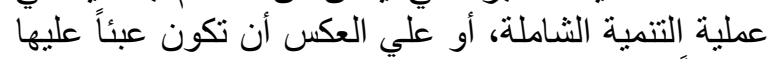

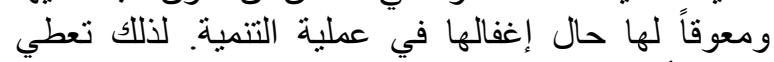

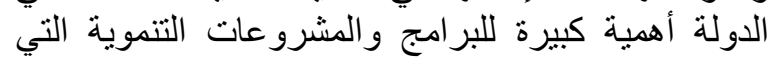

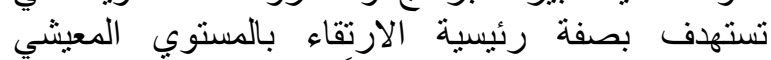

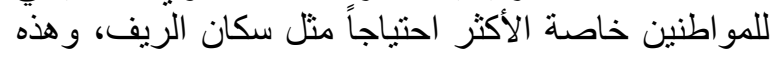

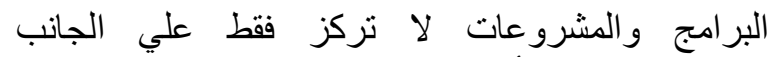

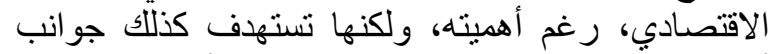

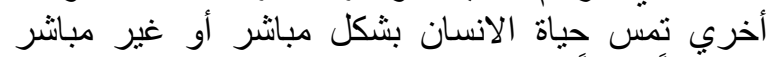

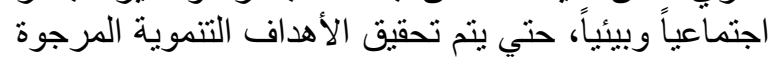

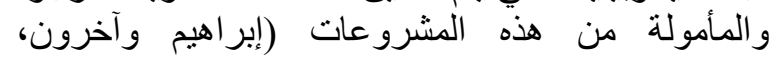

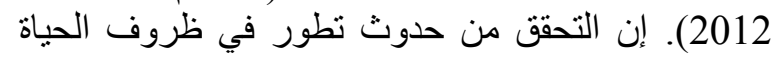

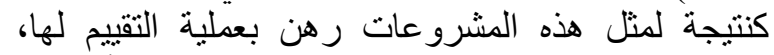

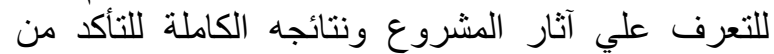

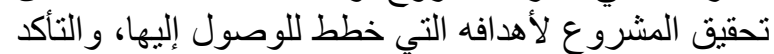

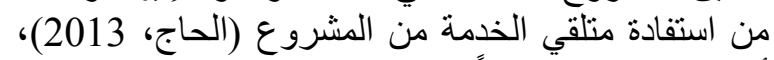

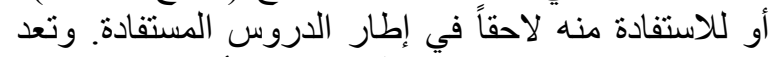

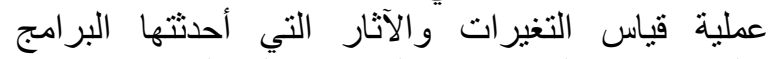

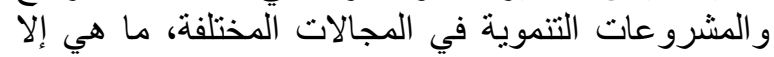

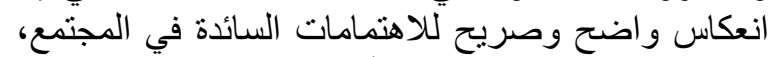

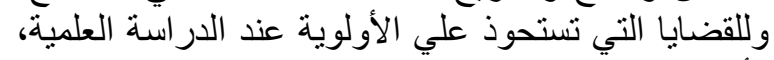

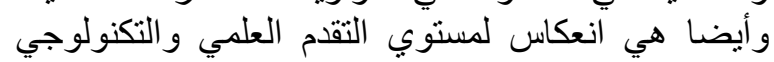

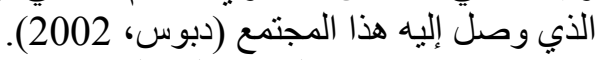

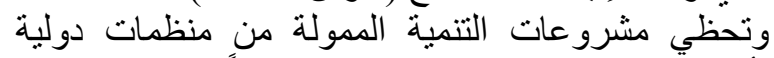
بأهمية متزي مثنة في الوعت التهية الراهن نظراً لاحتباج الدول

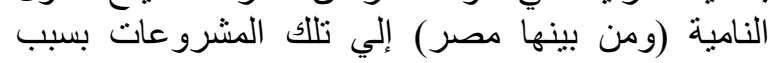

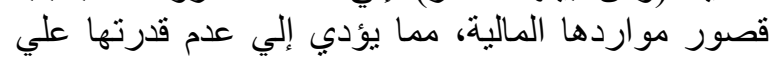

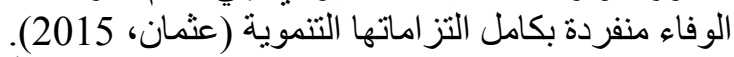

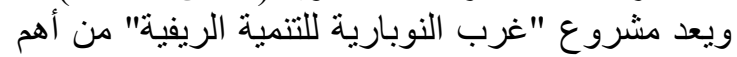

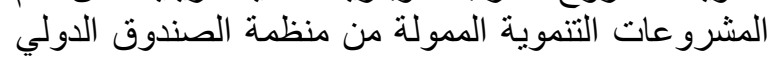

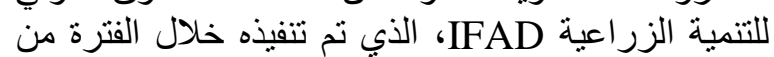
2003 إلي 2013، واستهدف الزبة

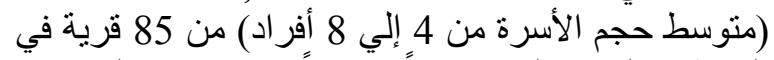

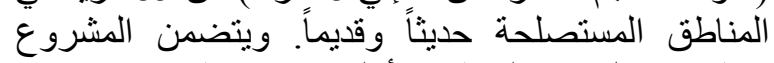

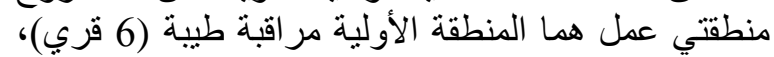

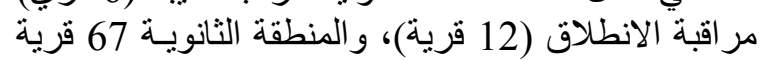

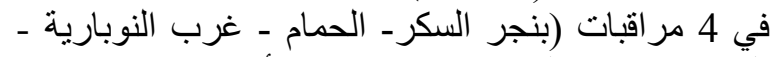
(البستان (وزارة الزر اعة واستصلاح الأر اضي، 2015) (IFAD ؛2014) 
ويمثل رأس المال الاجنماعي ايضاً حجر الزاوية في

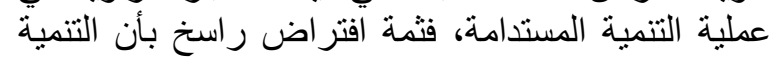

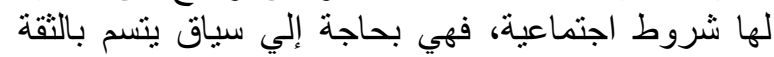

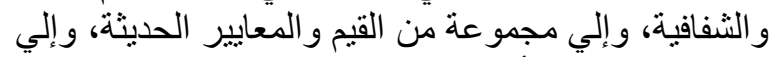

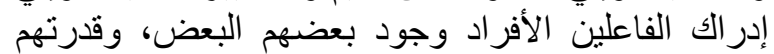

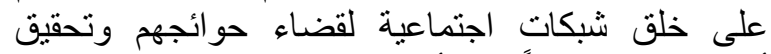

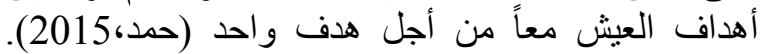

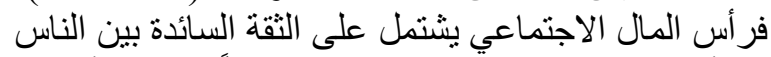

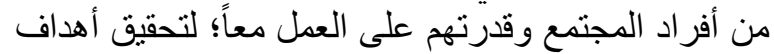

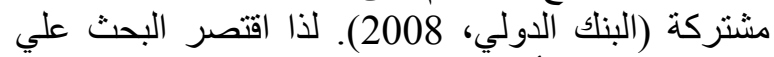
دراسة محوري رأس ألمال البشري والاجنماعي. لأني.

\section{3. أهداف الاراسة}

من التساؤلات السابقة ولتحقيق الغرض من الأرافة الدراسة يمكن صباغة الأهداف الآتية:

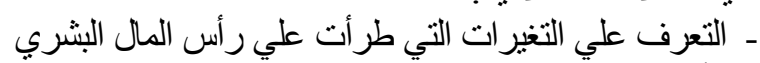

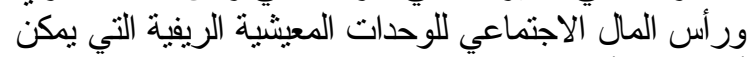

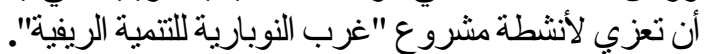

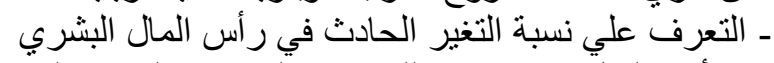
ور أس المال الاجتماعي للوحدات التية المعيشية الريفية التئية التئي

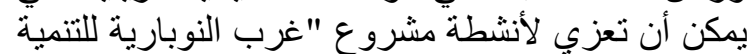
الريفية".

\section{4. الفروض الاحصائية \\ صيغت مجموعة من الفروض لتحقيق أهداف الدراسة،

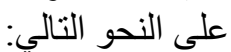 لا يوجد فروق معنوية في رأس المال البشري للوحدات

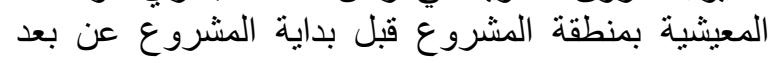 انتهاءه. لا يوجد فروق معنوية في رأس المال الاجتماعي للوحدات

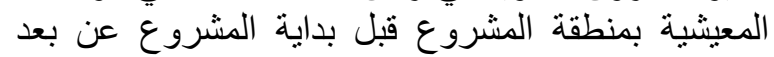 انتهاءه.}

\section{5. الطريقة البحثية}

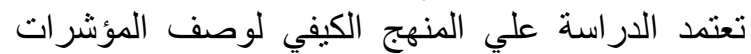

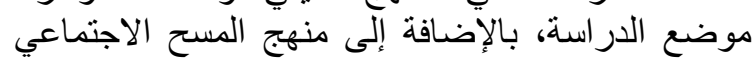

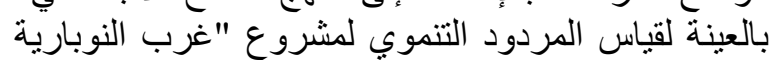

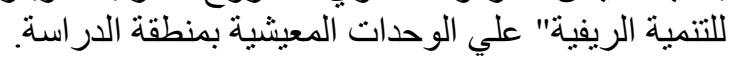

\section{6. عينة البحث البث}

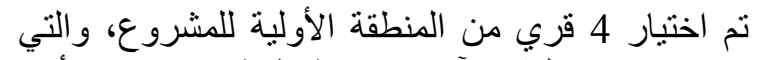

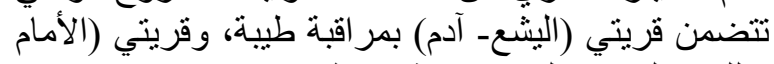

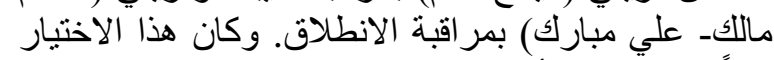

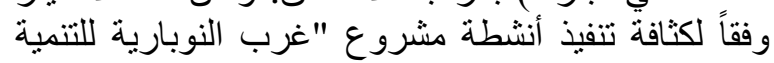

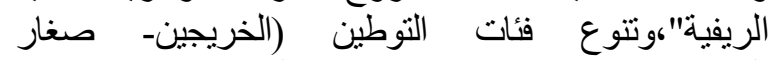
المزارعين- مضارين) (وزارة الزرين الزراعة واستصلاح الأر اضي، ونطين 2017).

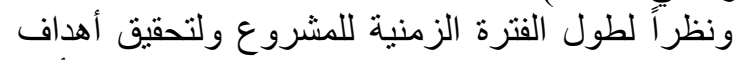

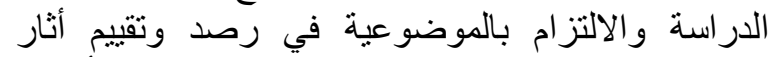
المشروع، نم اختيار عينة عشوائية بسيطة من أرباب
في البلدان النامية "مصر" (Mahalaya, 2010)، وكذلك الألك

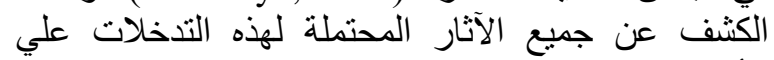

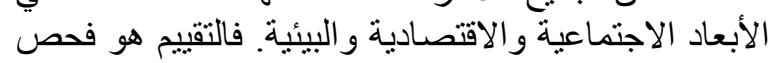

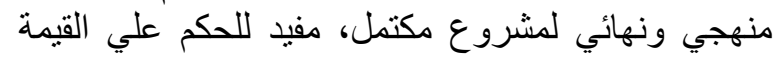

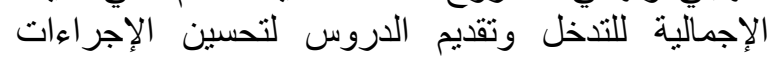

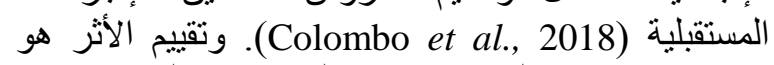
نوع خاص من التقييم يعتمد علي قياس التغير التيرات في الآني

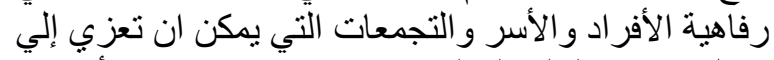

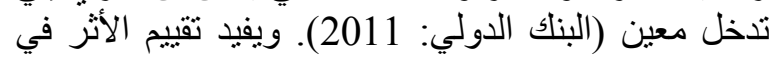

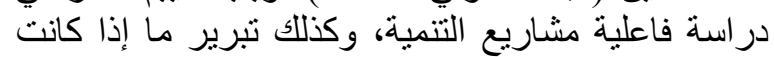
الأموال التي أنفقت في المشاريع قد ساهمت في في تحسين حياة الفقر اء (Mahalaya, 2010). وفي هذا الصدد أشار البنك الدولي إلي أنه ينبغني أن يكون

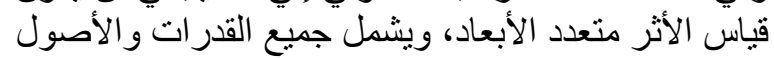

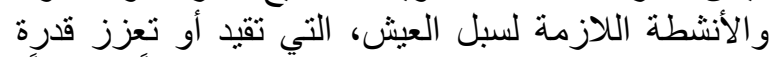

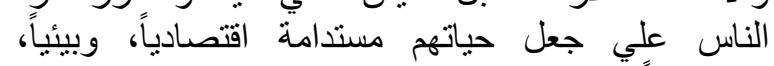
واجتماعياً (Colombo et al., 2018). لذا فقد تم اختبار منهج سبل العيش Livelihoods لتطبيقه

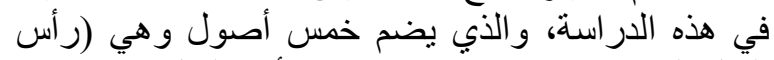

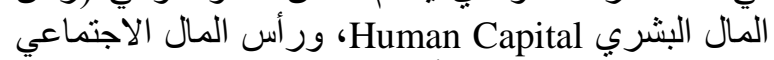
Physical Social Capital Capital

المال الطبيعي Natural Capital (Chen et al., 2013). ويشمل رأس المال البشري أصولاً مثل المعرفة

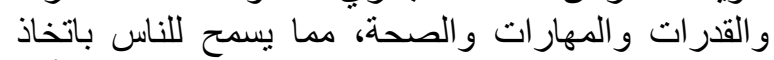

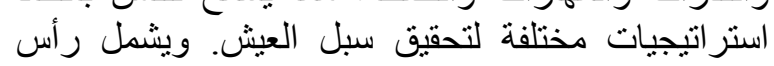

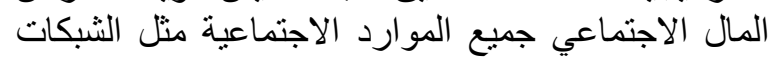

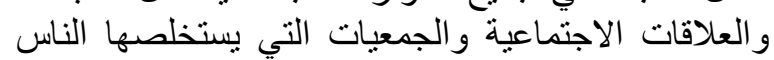

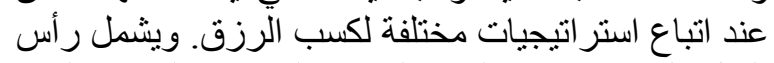

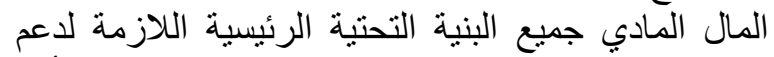

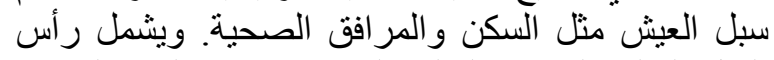

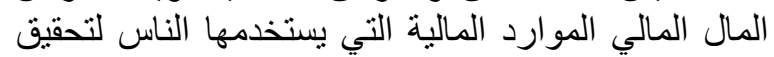

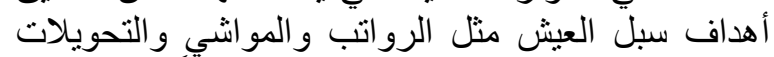

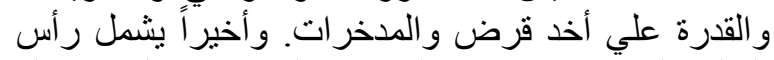

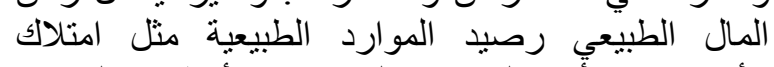

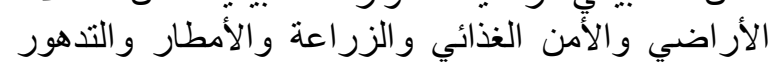

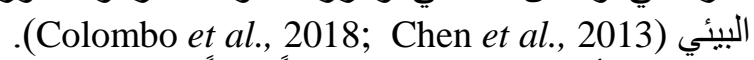
ويلعب رأس المال البشري دوراً هاماً في التنمية في البي

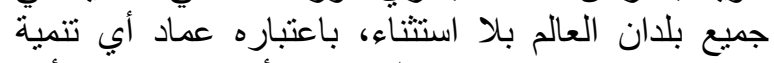

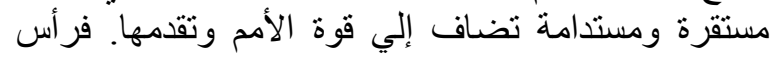

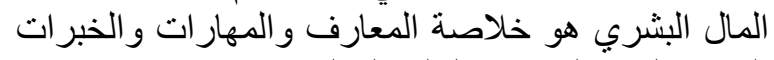

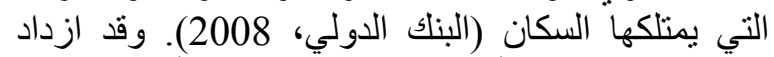

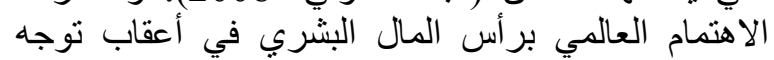

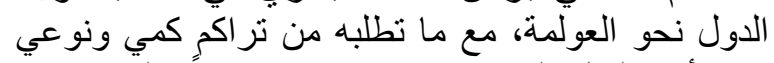

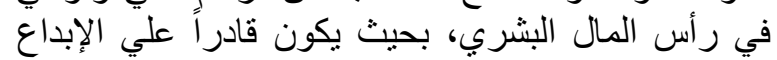

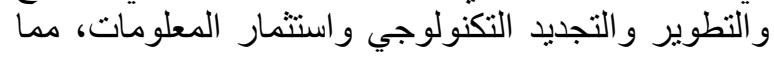

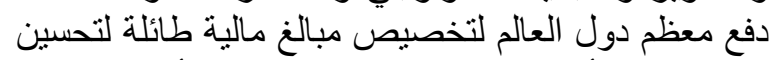

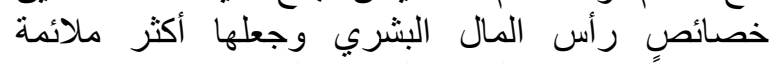
و انسجاماً مع منطلبات التنميةٍ المستدامة (ابراهيمي، 
منوسط المتغير في الفترة الثانية. بالفي

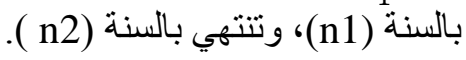

\section{9. التعريفات الإجرائية للمتفيرات}

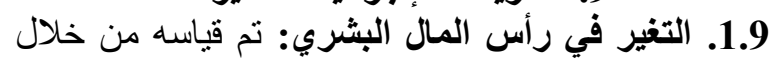

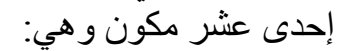

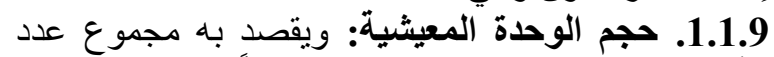
الأفراد (ذكور/ إناث) الذين يقيمون معاً في نفس الوحدة الوحدة

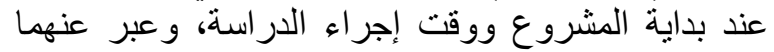

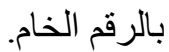

2.1.9. متوسط الحالة التعليمية لأفراد الوحدة المعيشية:

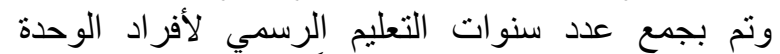

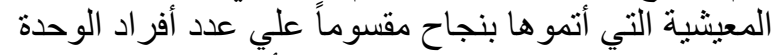

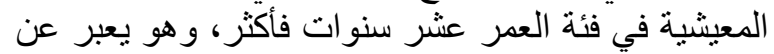

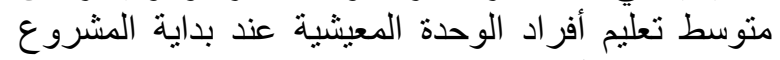
ووقت إجر اء الدراسة.

3.1.9. مدي تعرض الأرابة رابة الوحدة المعيثية للإصابة

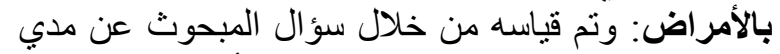
سلامة رب الوحدة المعيشية وخلوه من الأمر اض اضل المتوطنة

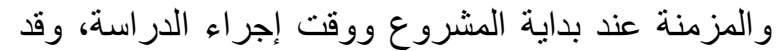

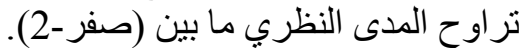

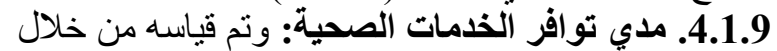

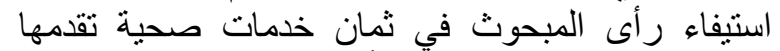
العيادات الطبية بالقرية أسبو عياً عند بداية المشروع ولئ ووقت

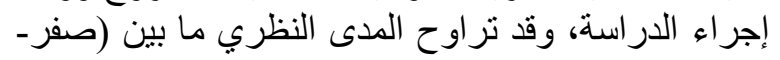
20 - 24 درجة). من خلأ مدي الاستفادة من الخدمات الصحية: وتم قياسه

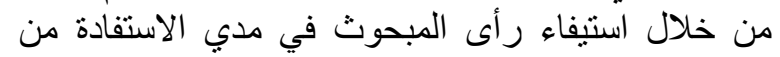
ثمان خدمات صحية تقدمها العيادات الطيبة باتية بالقرية الطية

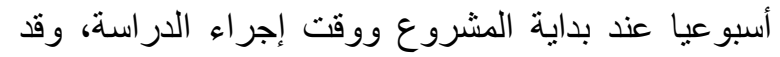

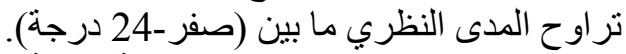
6.1.9. ممارسات الحفاظ علي خصوبة التربة : وتية وتم قياسه

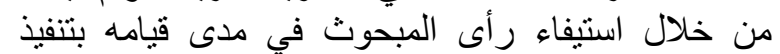

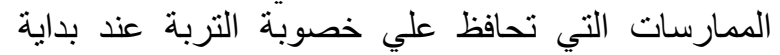

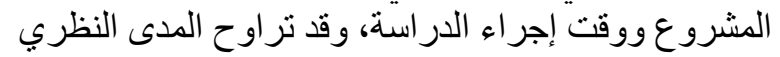
ما بين (صفر -6 درجة المجة).

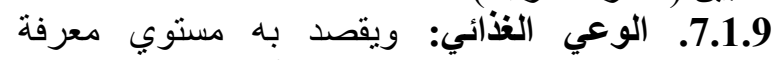

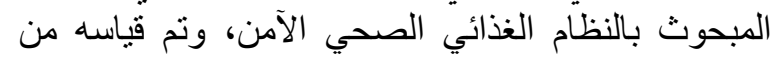

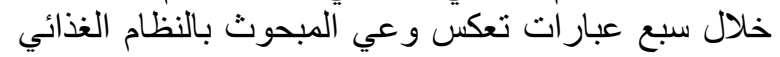

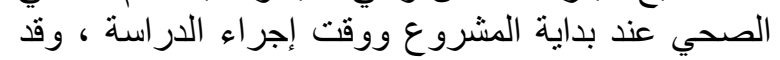

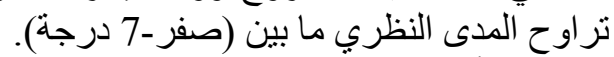

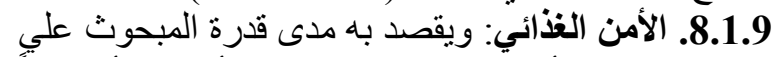
تلبية احتياجات أفراد الوحدة المعيشية الأساسية أسبوعياً

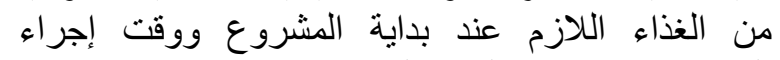

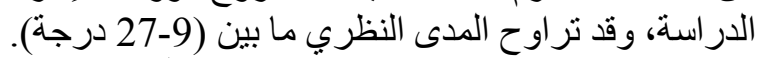

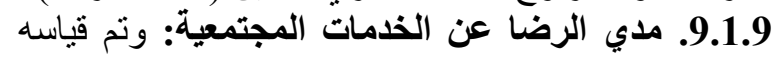

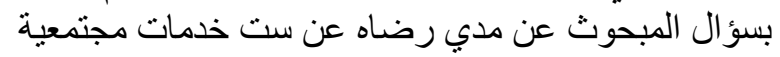

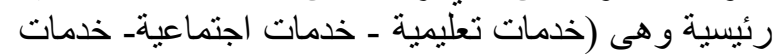
اقتصادية - خدمات دينيةـ المرافق والبنية الأساسيةـ
الوحدات المعيشية المستفيدين من أنشطة مشروع "التنمية

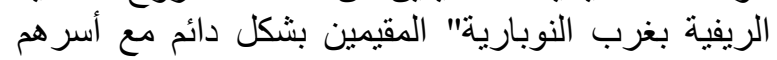
بالقري المختارة منذ بدءء عملية التوطين (المستفيد الاصلي المئي

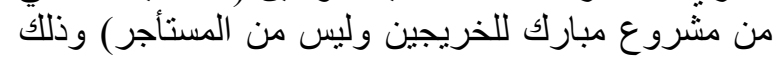

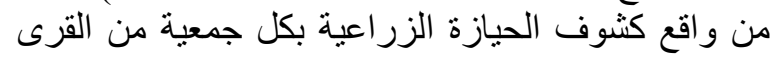

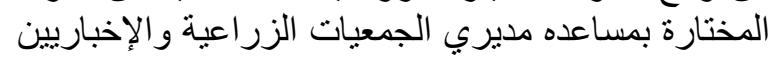

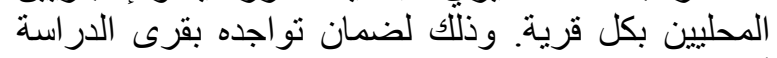

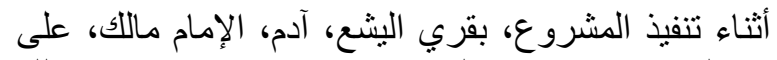

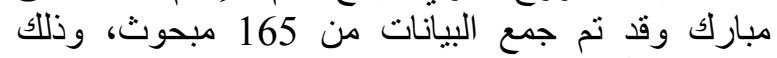

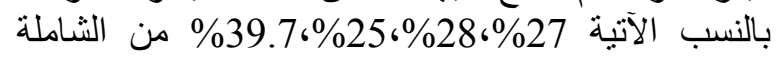
(144، 146، 200، 88 ) علي الترنيب.

\section{7. جمع البيانات}

تم جمع البيانات الميدانية باستخدام الاستبيان باتلات المقابلة

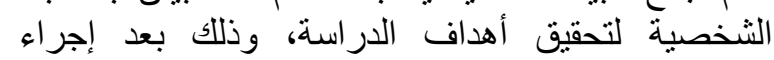

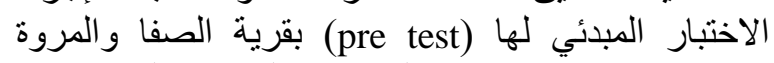

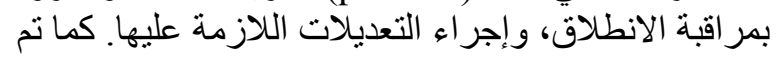

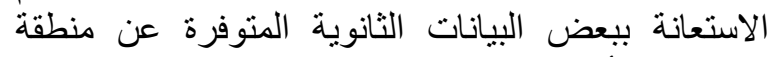

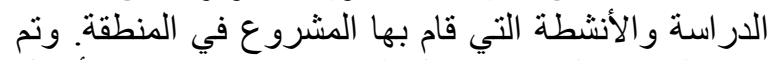

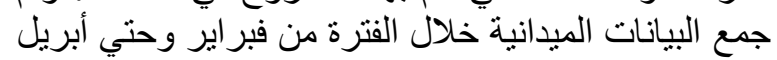

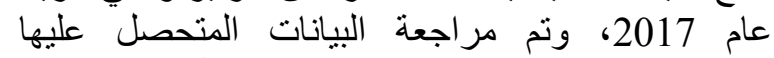
وترميزها وتفريغها باستخدام الحاسب الآئن الآلي بالاستعانة

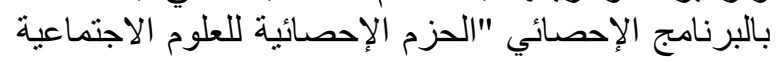

\section{8.}

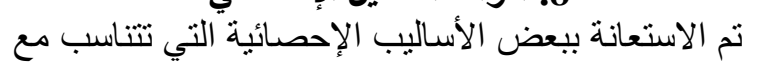

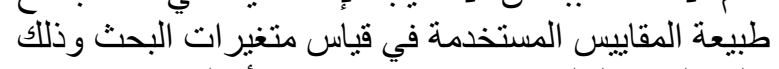
على النحو التالي: تم استخدام بعض الأساليب الإحصائية

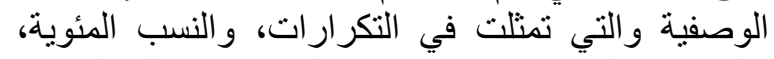

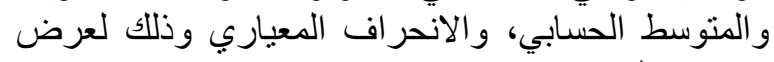
ووصف البيانات.

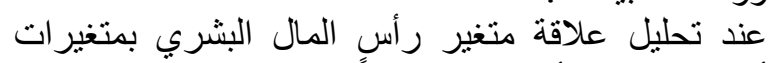

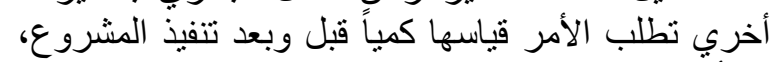

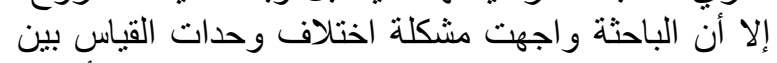

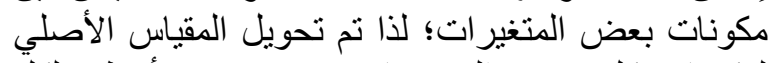

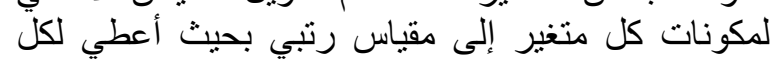

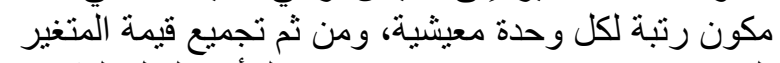

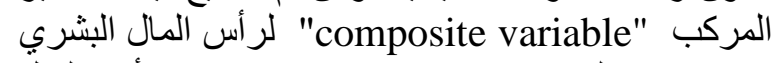

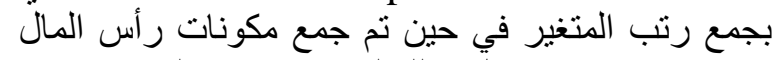

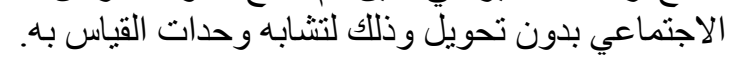

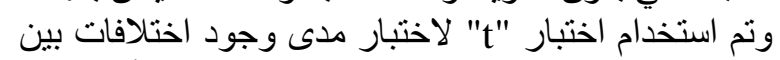

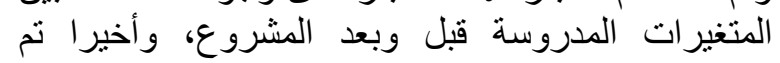

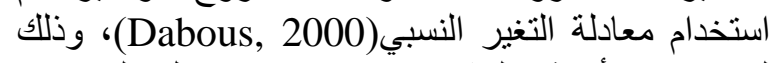

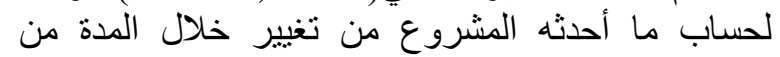

$$
2003 \text { إلي } 2017 \text { علي النحو التالي: }
$$

$$
\begin{aligned}
\int_{n}^{n_{2}} R C & =\left(k_{n_{2}}-K_{n_{1}}\right) / k_{n_{1}} * 100 \\
& =k_{n_{1}}
\end{aligned}
$$


أوضحت البيانات الواردة بجدول رقم (1)، أن ما يزيد

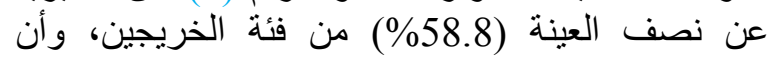

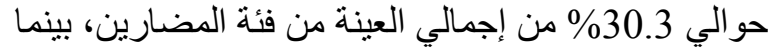
بلغت نسبة صغار المزارعين حوالي 10.9\% من إلينة إجمالي

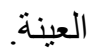
ويتضح أيضاً من جدول (1) أن ما يقرب من ثلاث

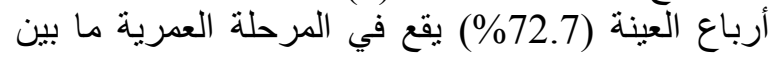

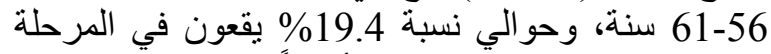

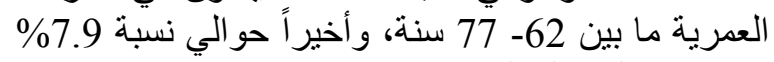

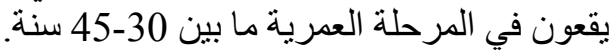

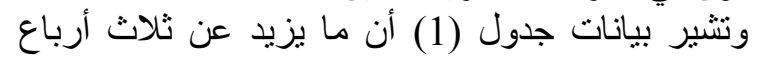

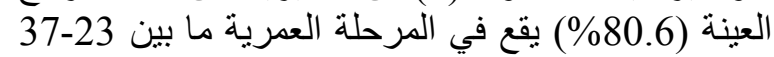

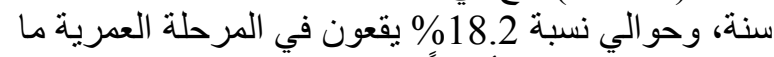

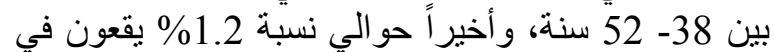
المرحلة العمرية ما بين 53 5- 68 ساخينة سينة. ويتضح أيضاً أن أغلبية أرباب الوحدات المعة المعيشية ذكور

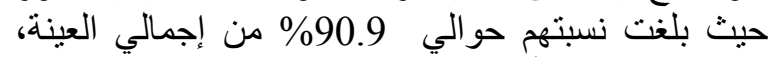
بينما بلغت نسبة أرباب الَّحدات المعيشية الإناث حوالي الئي

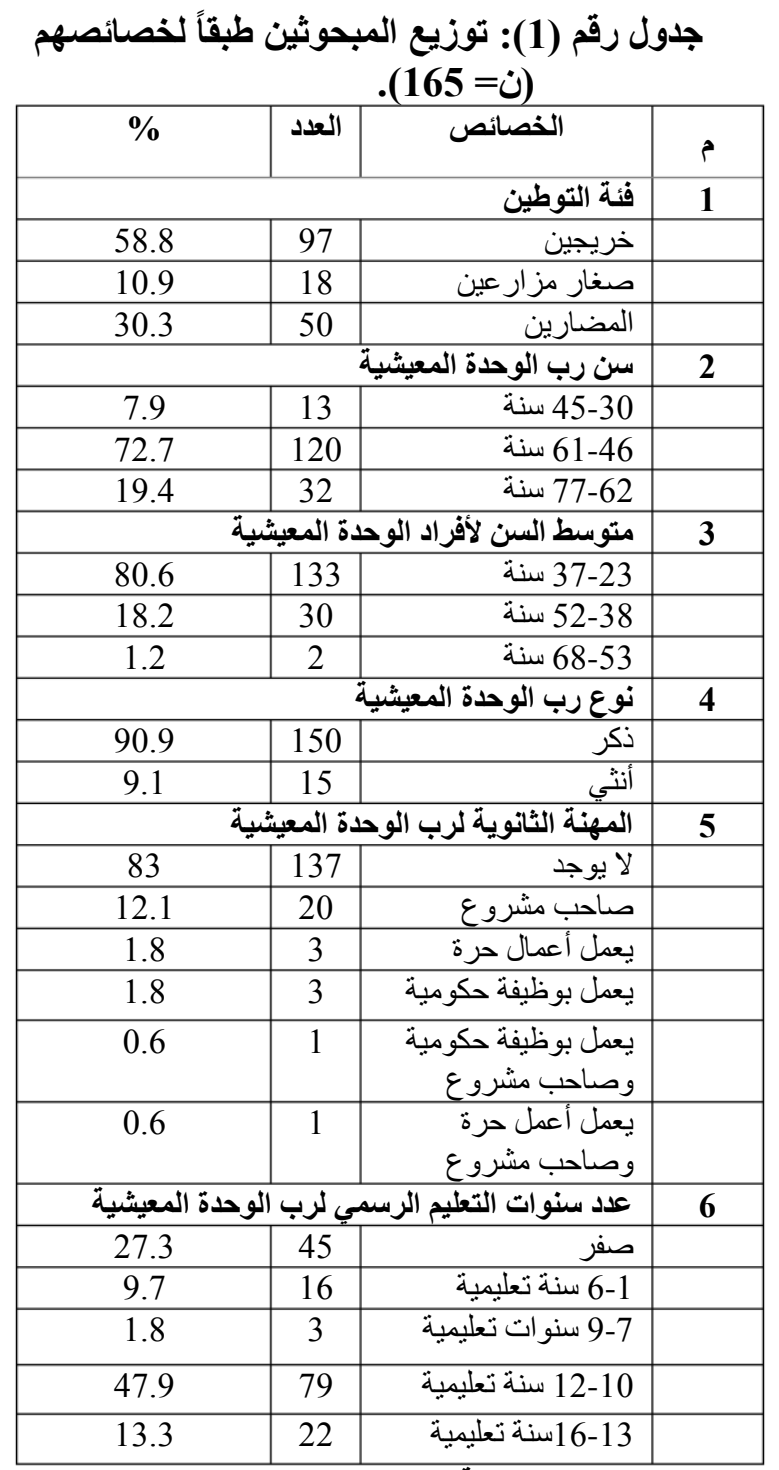

المصدر: نتائج الاراسة.
الخدمات التموينية) عند بداية المشروع ووقت إجراء الدراسة، وقد نراوح المدى النظري ما بين (صفر-51 والت

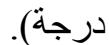
10.1.9. عدد الدورات التدريبية: وتم قياسه برقم خام

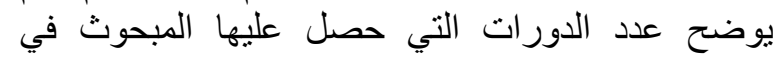

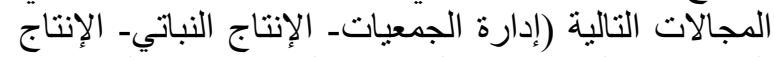

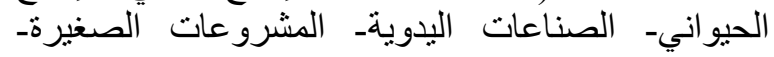
القيادة الريفية) عند بداية المشروع ووقت الئنة إجر اء الدراسة.

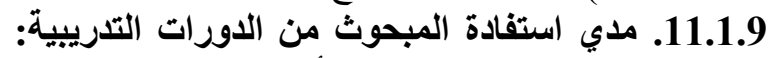

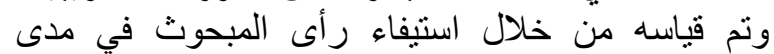

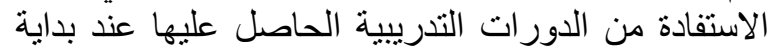

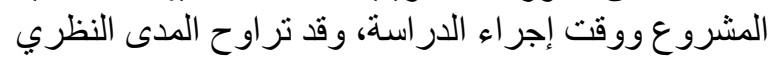
ما بين (صفر -39 درجة). 2.9. التغير في رأس المال الاجتماعي: وتم قياسه من

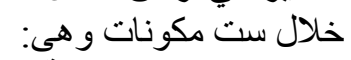

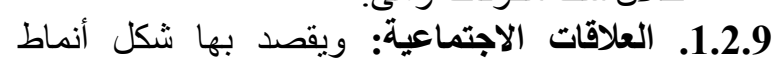

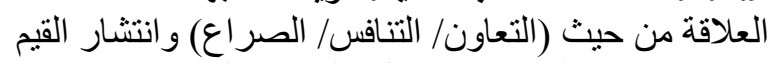

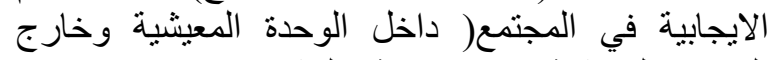

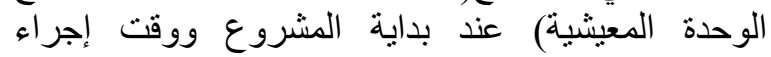

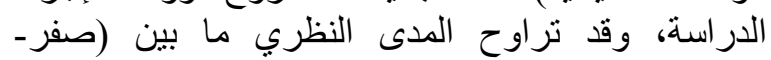

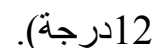
2.2.9. درجة القيادية: ويقصد به مدي لجوء أهل القدية القرية

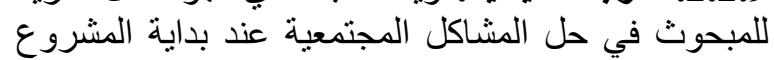

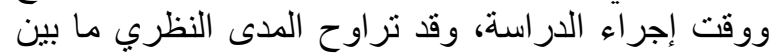

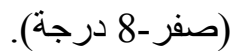

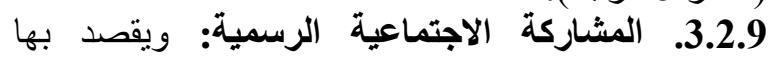

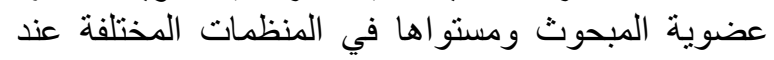

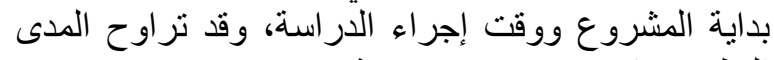

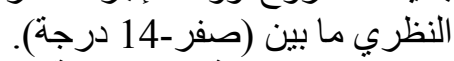
4.2.9. المشاركة الاجتماعية غير الرئ الرسمية: ونم قياسه

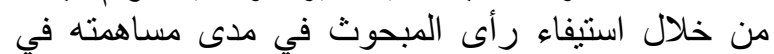

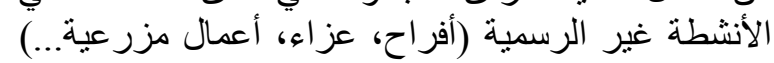

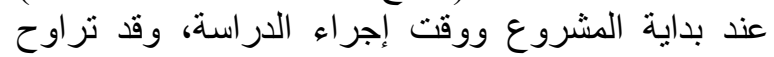

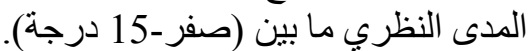

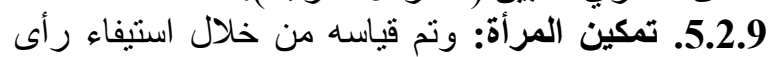
المبحوث في مدى مساهمه المرأة في التخاذ ألخداذ القرارات

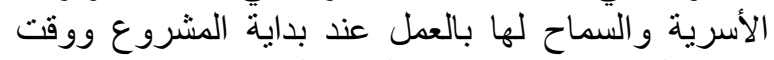

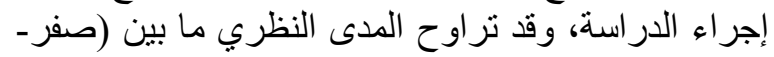
(10 10 6.2.9. المشاركة السياسية: ويقصد بها مدى مشاركة المبحوث وزوجته في التصويت التئة بالانتخابات (المحلية،

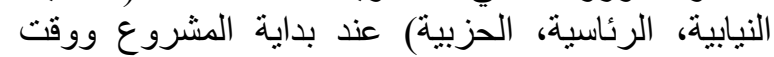

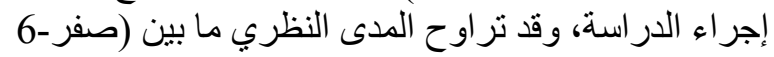
درجة). (المراء

\section{0. وصف العينة}

يتناول هذا الجزء عرضاً للنتائج الخاصة بوصة بوصف الإصف

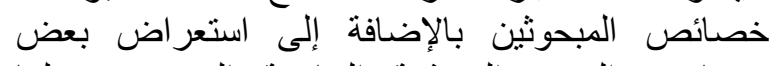

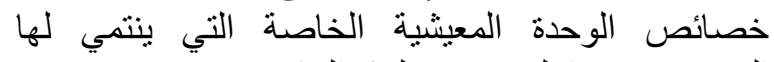

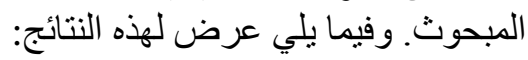


درجة قبل وبعد المشروع علي الترتيب، وبلغت نسبة المبحوثين في الفئة المنخفضة لمتوسط علئ عدد سنو ات التعليم

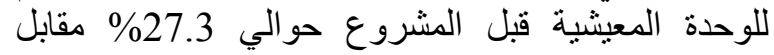
11.5 بعد المشروع، وبلغت نسبة المبحوثين في الفئة المتوسطة قبل المشروع حوالي 44.2\% مقابل بعد المشروع، وأخيراً بلغت نسبة المبحوثين في الفئة

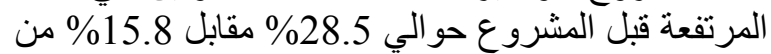

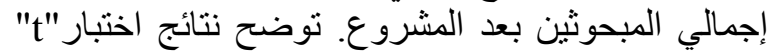

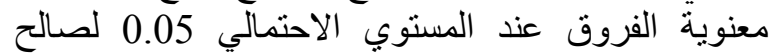

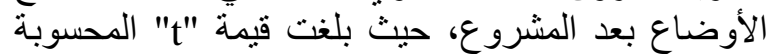

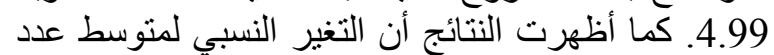

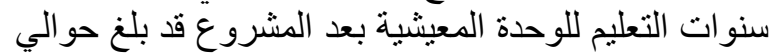

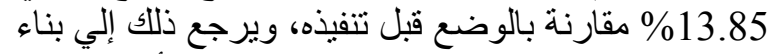
المشروع للمدارس وتثنيلها وفصول فئل محو الأمية بالعديد

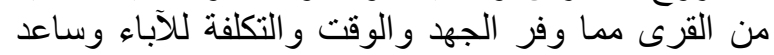
على استقرارهم حيث هناك العديد منهم كانوا بذهبون

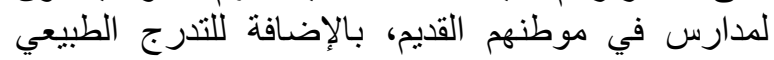
للمر احل التعليمية نتيجة طول فترة تنفيذ المشروع و التئي بلغت 10 سنوات. تبين النتائج الواردة بجدول

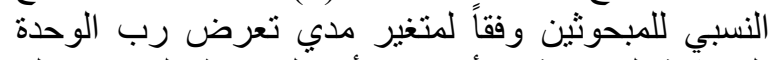

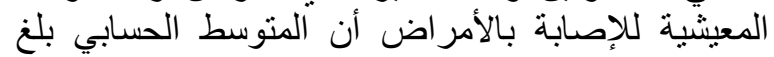

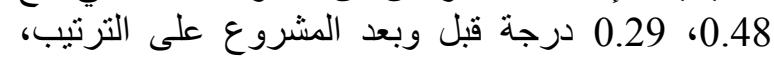

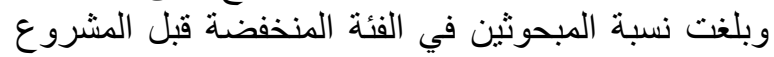

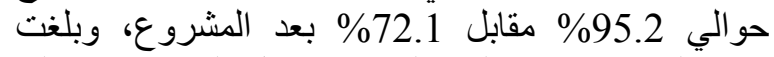

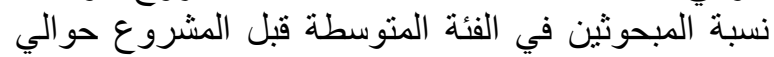

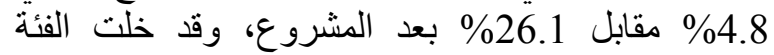

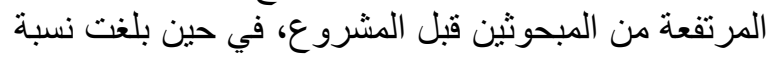

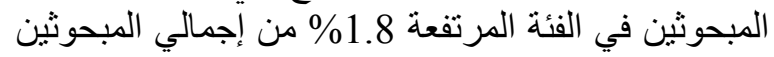

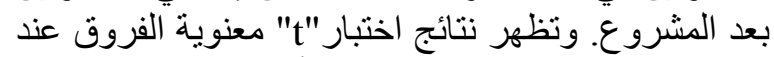

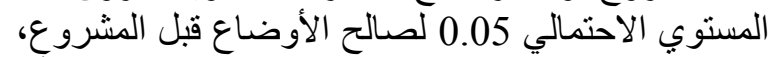

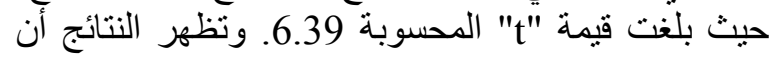

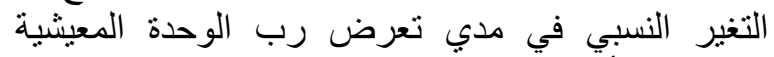

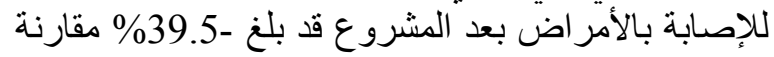

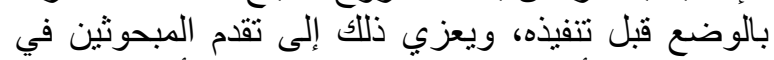

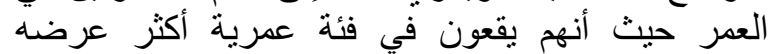

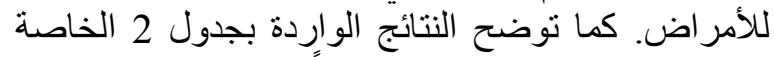

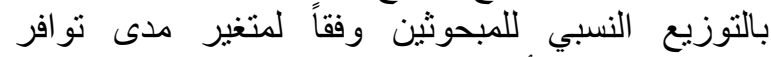

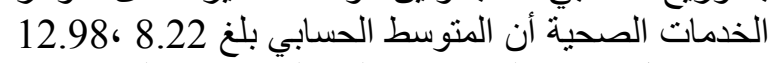
درجة قبل وبعد المشروع على المئل الترتيب، وبلغت المبت نسبة

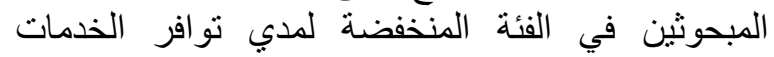

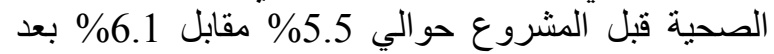

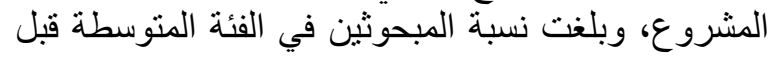

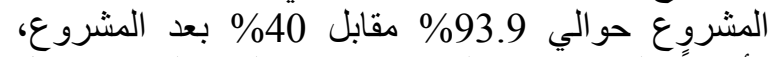
وأخيراً بلغت نسبة المبحوثين في الفئة المرتفعة قبل

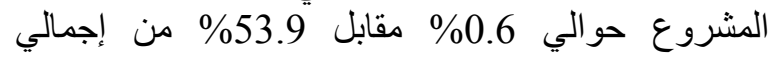

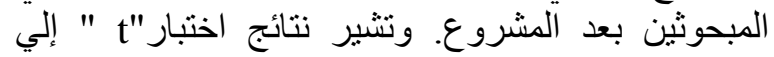

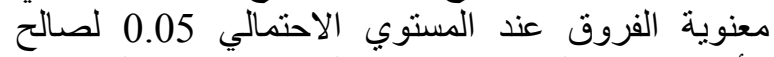

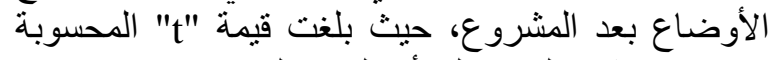
12.80. وتثير النتائج إلي أن التغير النسبي في مدى تو افر النية
9.1 تبين من بين العينة التي تمتهن الزينة الزراعة كمهنة رئينية

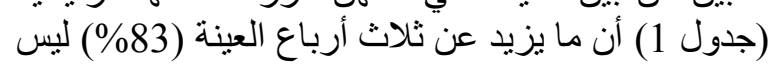

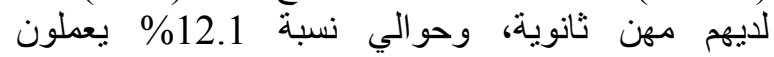

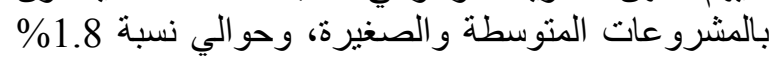

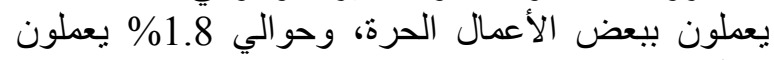
بوظيفة حكومية. ويوضح (جدول 1) أيضاً أن ما يقرب من نصف العينة

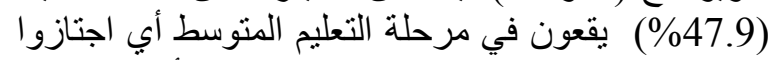

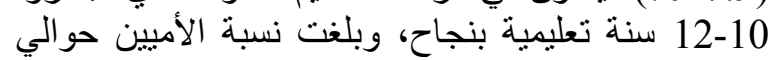

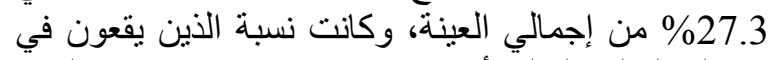

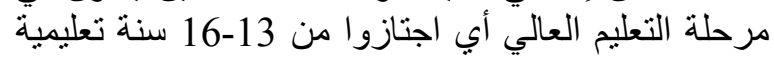

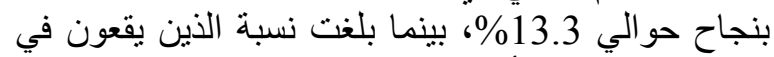

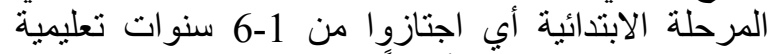

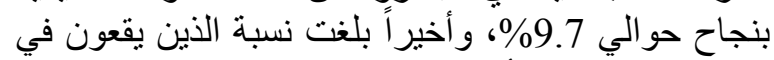

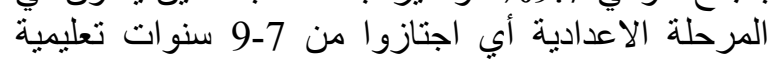
بنجاح حو الي 1.8\% من إعادية إينازي العنانة. 11. النتائج ومناقشتئها

يشتمل هذا الجزء علي عرض ومناقتة النتائج الخاصة

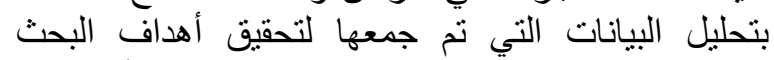

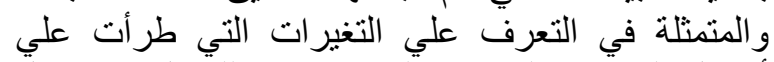

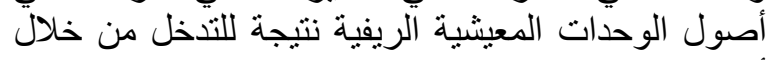

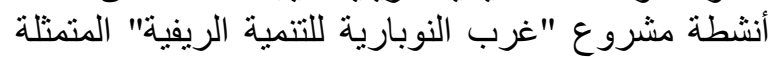

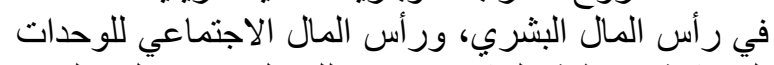

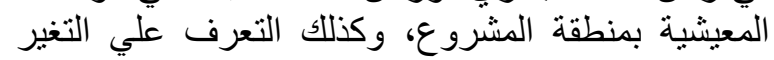

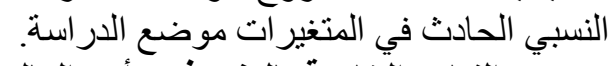
1.11. النتائج الخاصة بالتغير في رأس المال البشري النئ للمبحوثين

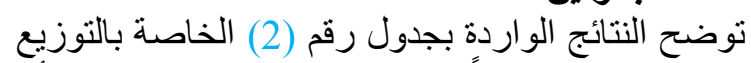

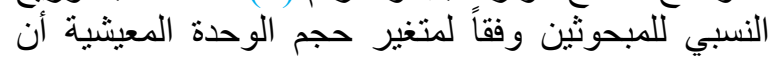

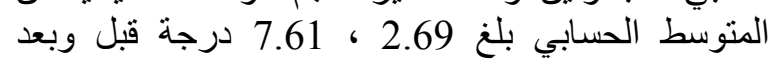
المشروع علي الترتيب، وبلغت نسبة المبحوثين في الفئة

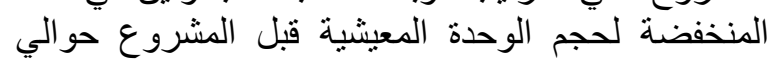

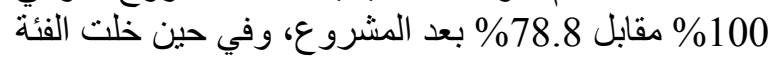

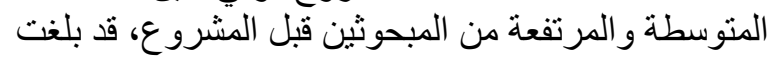

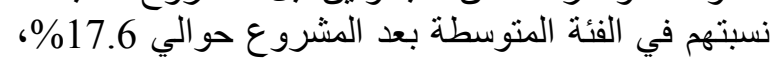
وفي الفئة المرتفعة حوالي 3.6\% من بندة إجمالي المبحوثين

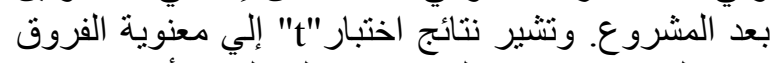

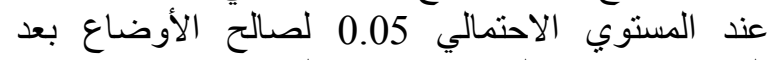

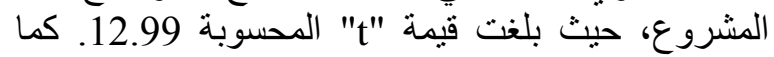
تشير النتائج إلي ان التغير النسبي في حجم الوحدة المعيشية

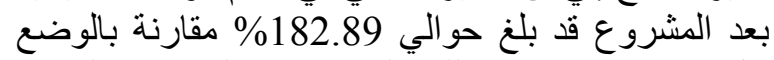

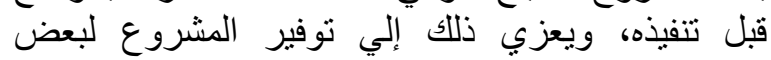

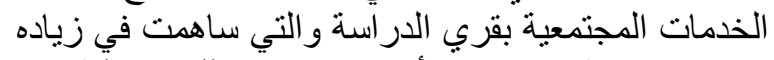

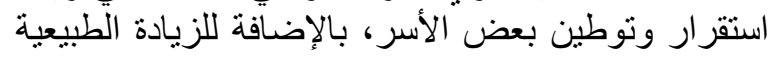
للسكان نتيجة طول فترة تنفيذ المشروع و الإضئ لازيادي بلغت 10

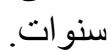

تظهر النتائج الواردة بجدول (2) و الخاصة بالتوزيع النسبي للمبحوثين وفقاً لنتغير منوسط الحولئ الحالة التعليمية للوحدة المعيشية أن المتوسط الحسابي بلغ لمنئ 7.58، 8.63 
وتظهر النتائج الواردة بجدول (2) الخاصة بالتوزيع النسبي للمبحوثين وفقاً لمتغير مدى الاستفادة من الخدمات التهات

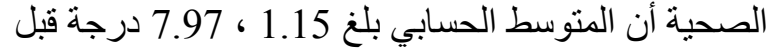
وبعد المشروع على الترتيب، وبلغت نسبة المبن المبحوثين في في

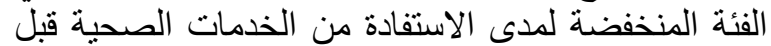

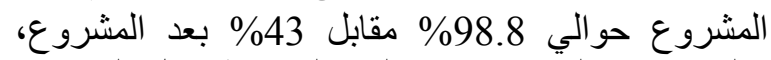

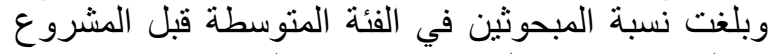

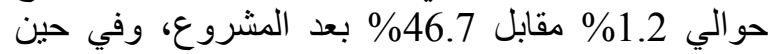

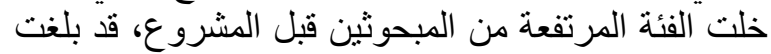

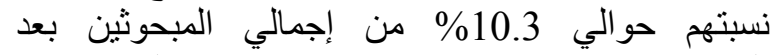

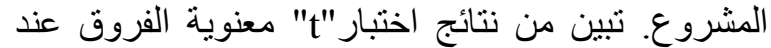

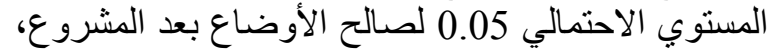

الخدمات الصحية بعد المشروع قد بلغ حوالي 57.9\% مقارنة بالوضع قبل تنفيذه، ويرجع ذلئن اللك إلى نوفير

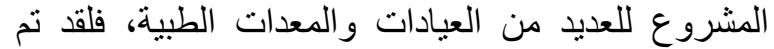

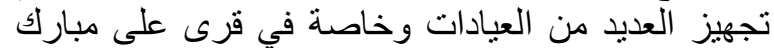

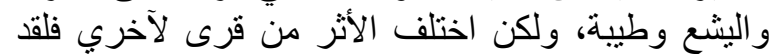

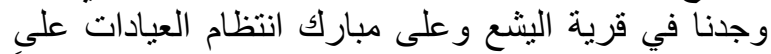

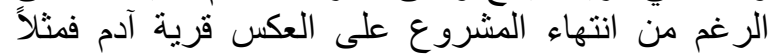

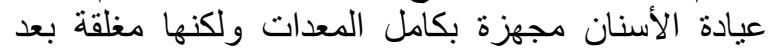

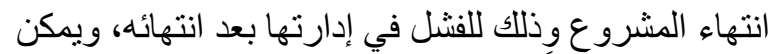

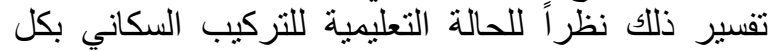

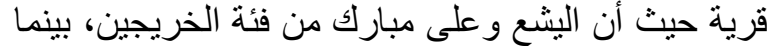
آدم تضم فئتي الخريجين و المنتفعين.

جدول رقم (2): التوزيع النسبي لعينة الدراسة لمحاور رأس المال البشري.

\begin{tabular}{|c|c|c|c|c|c|c|c|c|c|c|c|c|}
\hline \multirow{3}{*}{ قيمة "t" } & \multicolumn{6}{|c|}{ الفئات } & \multirow{3}{*}{ Std } & \multirow{3}{*}{$\bar{x}$} & \multicolumn{2}{|c|}{ المدي الفعلي } & \multirow{3}{*}{ القترة } & \multirow{3}{*}{ المتغير } \\
\hline & \multicolumn{2}{|c|}{ مرتفعة } & \multicolumn{2}{|c|}{ متوسطة } & \multicolumn{2}{|c|}{ منخفضة } & & & 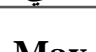 & Mi & & \\
\hline & $\%$ & عدد & $\%$ & عدد & $\%$ & عدد & & & Max & Mimn & & \\
\hline \multirow{2}{*}{$12.99^{*}$} & 0 & 0 & 0 & 0 & 100 & 165 & 1.68 & 2.69 & 9 & 1 & قبل & \multirow{2}{*}{ المجميشية الوحدة } \\
\hline & 3.6 & 6 & 17.6 & 29 & 78.8 & 130 & 4.64 & 7.61 & 29 & 2 & بعد & \\
\hline \multirow{2}{*}{$4.99^{*}$} & 28.5 & 47 & 44.2 & 73 & 27.3 & 45 & 4.59 & 7.58 & 16 & $\mathbf{0}$ & قبل & \multirow{2}{*}{ التمالة } \\
\hline & 15.8 & 26 & 72.7 & 120 & 11.5 & 19 & 3.26 & 8.63 & 16 & $\mathbf{0}$ & بعد & \\
\hline \multirow{2}{*}{$6.39^{*}$} & $\mathbf{0}$ & $\mathbf{0}$ & 4.8 & 8 & 95.2 & 157 & 0.21 & 0.48 & 1 & $\mathbf{0}$ & قبل & \multirow{2}{*}{ بالألمراض } \\
\hline & 1.8 & 3 & 26.1 & 43 & 72.1 & 119 & 0.49 & 0.29 & 2 & 0 & بعد & \\
\hline \multirow{2}{*}{$12.80^{*}$} & 0.6 & 1 & 93.9 & 155 & 5.5 & 9 & 2.08 & 8.22 & 16 & $\mathbf{0}$ & قببل & \multirow{2}{*}{ مدي تواتر } \\
\hline & 53.9 & 89 & 40 & 66 & 6.1 & 10 & 4.34 & 12.98 & 19 & $\mathbf{0}$ & بعد & \\
\hline \multirow[b]{2}{*}{$18.87^{*}$} & $\mathbf{0}$ & $\mathbf{0}$ & 1.2 & 2 & 98.8 & 163 & 1.31 & 1.15 & 8 & $\mathbf{0}$ & قببل & \multirow{2}{*}{ الاستفادة من الضدمات } \\
\hline & 10.3 & 17 & 46.7 & 77 & 43 & 71 & 4.89 & 7.97 & 21 & $\mathbf{0}$ & بعد & \\
\hline \multirow[b]{2}{*}{$18.52^{*}$} & $\mathbf{0}$ & $\mathbf{0}$ & 4.8 & 8 & 95.2 & 157 & 0.66 & 0.27 & 4 & $\mathbf{0}$ & قبِل & \multirow{2}{*}{ الحفاظ علي } \\
\hline & 4.2 & 7 & 69.7 & 115 & 26.1 & 43 & 1.38 & 2.40 & 6 & 0 & بعد & \\
\hline \multirow{2}{*}{$10.57^{*}$} & 32.1 & 53 & 37 & 61 & 30.9 & 51 & 2.69 & 3.46 & 7 & $\mathbf{0}$ & قبل & \multirow{2}{*}{ الغذائي } \\
\hline & 69.1 & 114 & 13.9 & 23 & 17 & 28 & 2.60 & 5.33 & 7 & $\mathbf{0}$ & بعد & \\
\hline \multirow{2}{*}{$8.26^{*}$} & 29.7 & 49 & 36.4 & 60 & 33.9 & 56 & 6.74 & 17.47 & 27 & 9 & قببل & \multirow{2}{*}{ الآمن الغذائي } \\
\hline & 73.3 & 121 & 20.6 & 34 & 6.1 & 10 & 4.93 & 23.53 & 27 & 9 & بعد & \\
\hline \multirow{2}{*}{$31.26^{*}$} & 0.6 & 1 & 46.1 & 76 & 53.3 & 88 & 5 & 18.18 & 36 & 4 & قببل & \multirow{2}{*}{ عن الخديمات الرضات } \\
\hline & 59.4 & 98 & 40.6 & 67 & $\mathbf{0}$ & 0 & 5.93 & 34.76 & 48 & 21 & بعد & \\
\hline \multirow{2}{*}{$8.31^{*}$} & $\mathbf{0}$ & $\mathbf{0}$ & $\mathbf{0}$ & $\mathbf{0}$ & 100 & 165 & 2.57 & 0.76 & 26 & $\mathbf{0}$ & قبل & عدد الدورات \\
\hline & 3.6 & 6 & 7.9 & 13 & 88.5 & 146 & 38.41 & 25.26 & 190 & $\mathbf{0}$ & بعد & التدريبية \\
\hline & $\mathbf{0}$ & $\mathbf{0}$ & $\mathbf{0}$ & $\mathbf{0}$ & 100 & 165 & 1.76 & 1.2 & 12 & $\mathbf{0}$ & قبل & لدرجة \\
\hline $14.71^{*}$ & 7.9 & 13 & 27.9 & 46 & 64.2 & 106 & 9.13 & 11.47 & 39 & O & بعد & الألتقادة من \\
\hline $29.33^{*}$ & $\mathbf{0}$ & $\mathbf{0}$ & 35.2 & 58 & 64.8 & 107 & 1.90 & 15.51 & 20 & 12 & قبل & \\
\hline 29.33 & 36.4 & 60 & 62.4 & 103 & 1.2 & 2 & 2.08 & 20.89 & 26 & 16 & بعد & الإجه \\
\hline
\end{tabular}


قبل الشروع حو الي 29.7\% مقابل 73.3\% من إجمالي

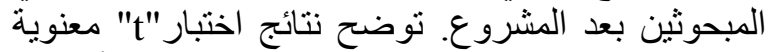

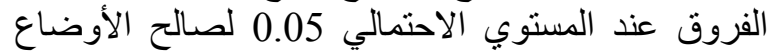

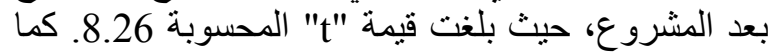

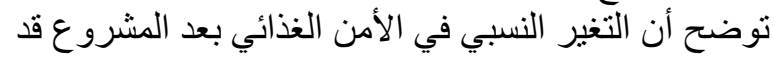

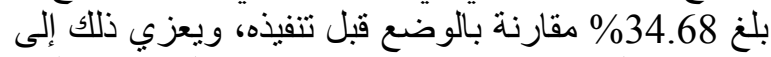

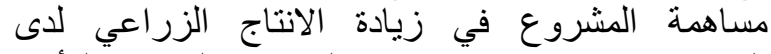
المبحوثين، مما ساهم في رفع المستوي المئي المعيشي للأسر

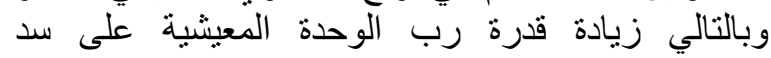
الاحتياجات الغذائية المختلفة.

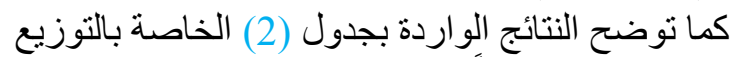

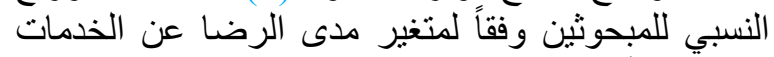

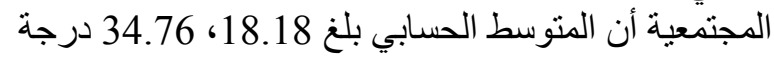
فبل وبعد المشروع علي الترتيب، وبلغت نسبة المبن المبحوثين

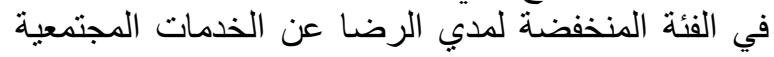

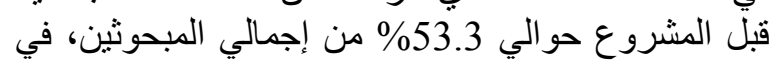

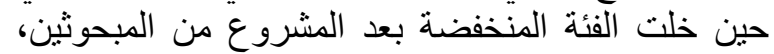

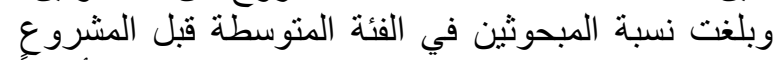

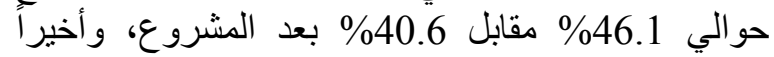

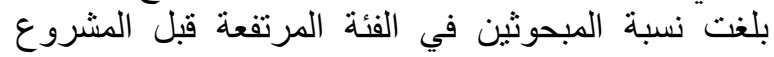

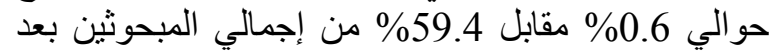

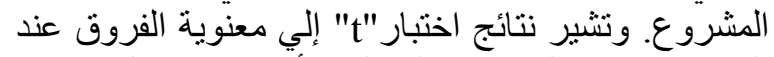

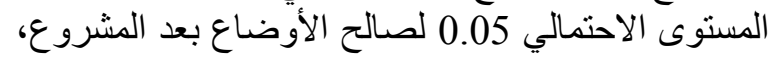
حيث بلغت قيمة "t" المحسوبة 31.26. كما تشير الأبير النتائج إلي أن التغير النسبي في مدي الرئ الرضا عن الخدات

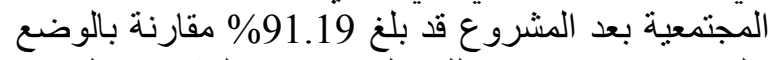

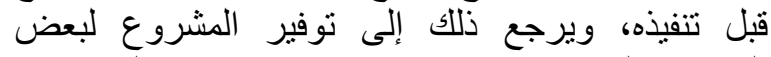

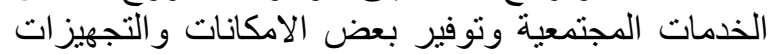
لزيادة فاعلية بعض الخدمات التونئ.

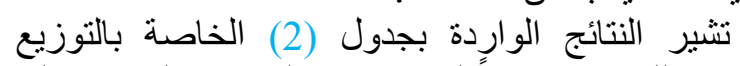

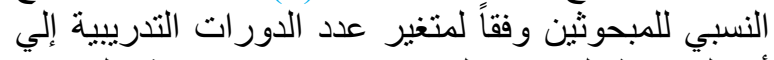
أن المتوسط الحسابي بلغ 0.76، المشروع علي الترتيب، وبلغت نسبة المبل المبحوثين في الفئة

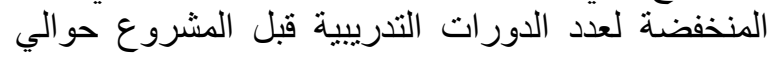

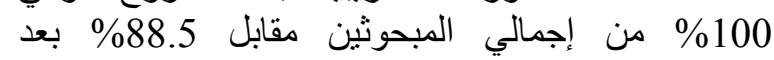

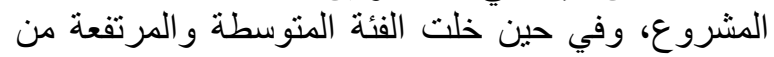

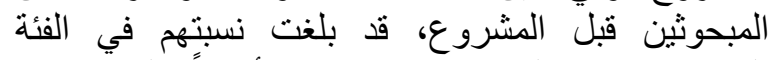

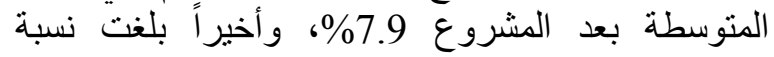

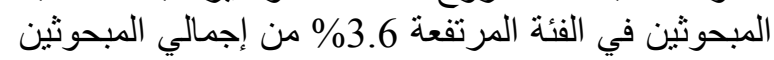

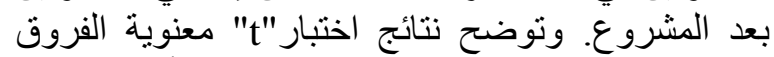

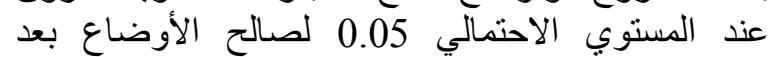

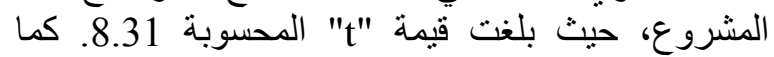

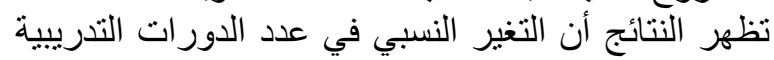
بعد المشروع قد بلغ 3223.68\% مقارنة بالوضير بالوضع قبل تنفيذه.

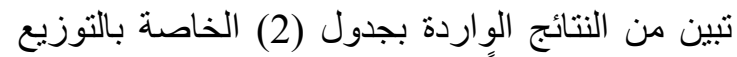

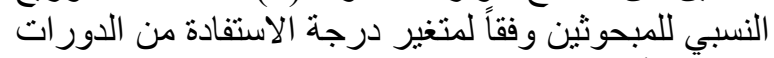

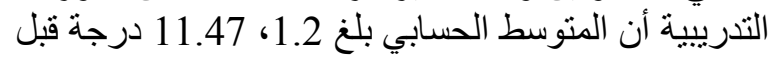

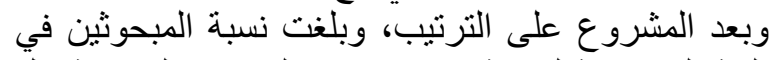

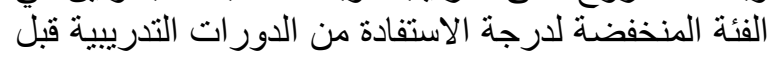

حيث بلغت قيمة "t" المحسوبة 18.87. كما تبين من الأن التئ النتائج أن التغير النسبي في مدى الاستفادة من الخدمات

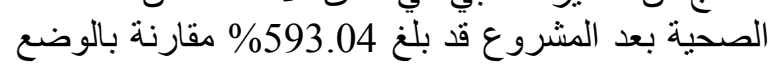

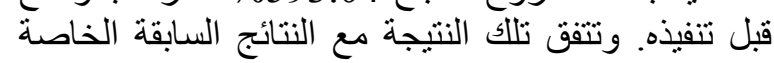

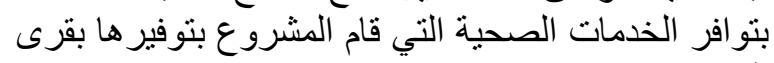

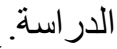
وايضاً توضح النتائج الواردة بجدول (2) الخاصة

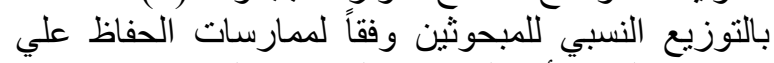

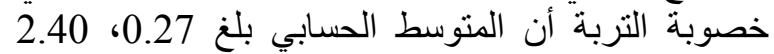
درجة قبل وبعد المشروع على الترنية الترنيب، وبلغت نسبة

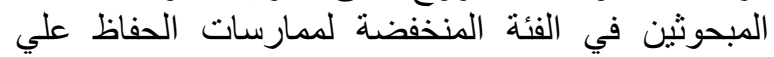

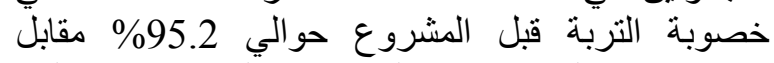

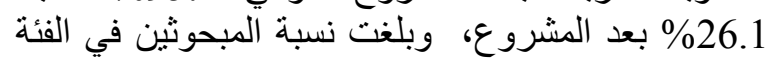

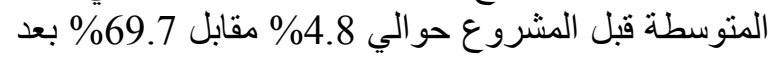

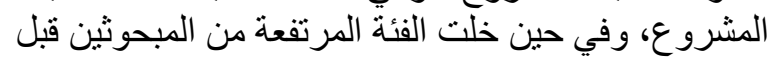

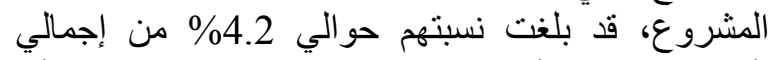

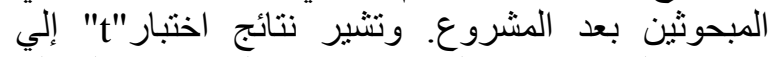

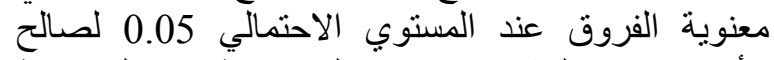

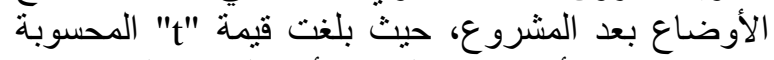

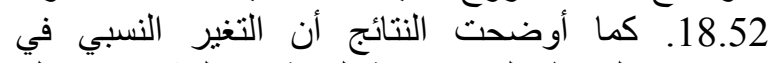

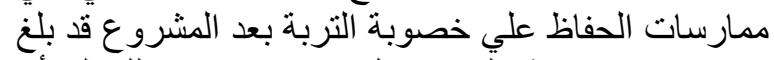

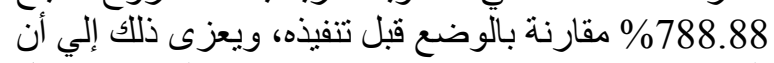

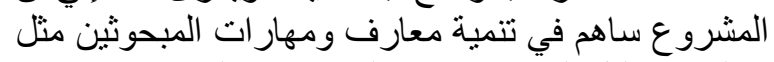

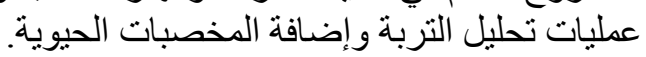

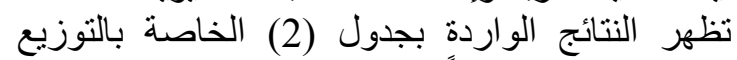

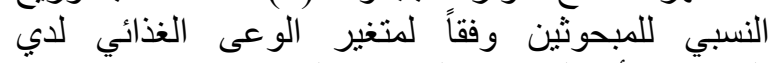

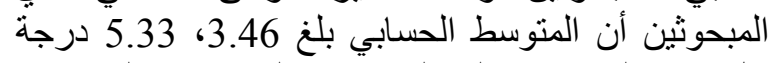

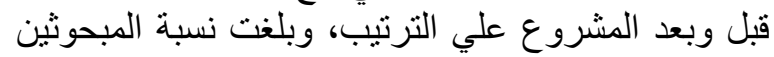

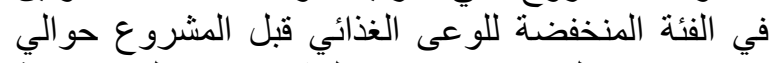

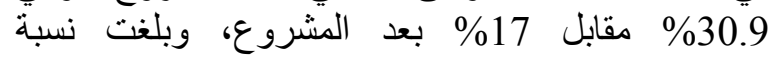

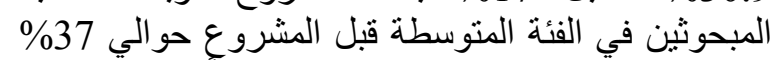

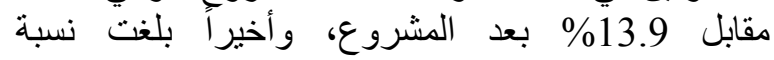

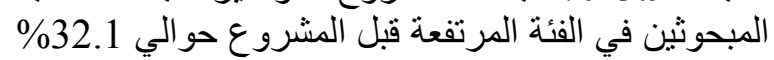

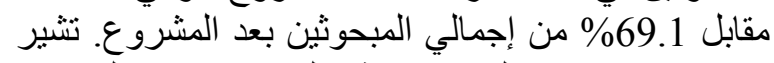

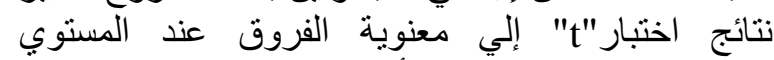

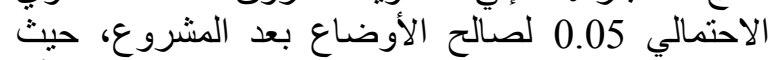

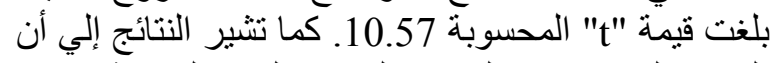

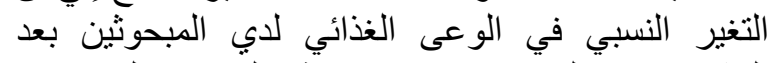

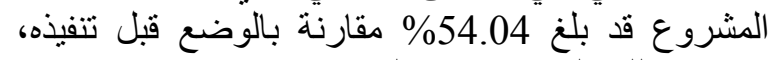

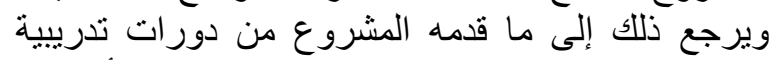

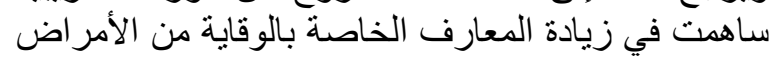
وطرق التغنية الصحية.

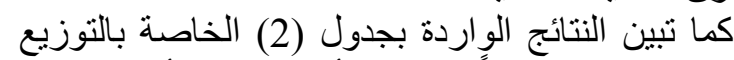

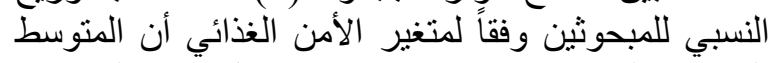

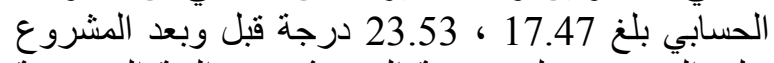
علي الترتيب، وبلغت نسبة المبحوثين في الفئة المنخفضة فئنة

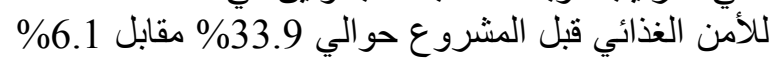
بعد المشروع، وبلغت نسبة المبحوثئن في المبن الفئة المتوسطة

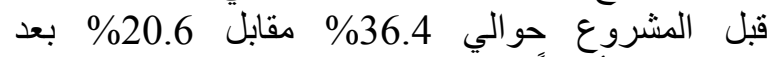
المشروع، وأخيراً بلغت نسبة المبحوثين في الفئة المرتفعة بعة 
القرية، فربما يرجع إلى مشاركتهم في الدورات التدريبية

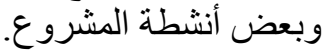
كما تظهر النتائج في (جدول

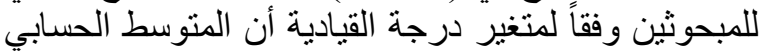

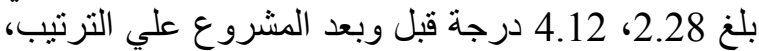
وبلغت نسبة المبحوثين في الفئة المنخفضة لدئة لدرجة القئ القيادية

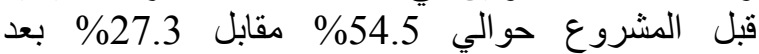
المشروع، وبلغت نسبة المبحوثين في الفئة المتوسطة قبل

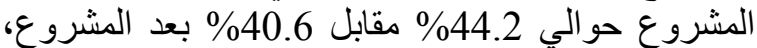

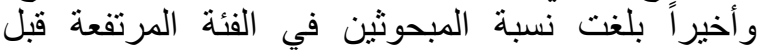

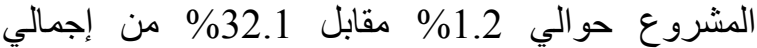

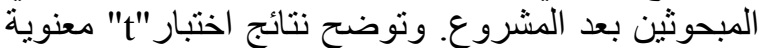

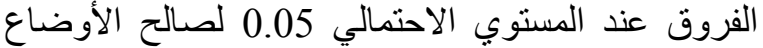

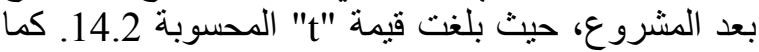

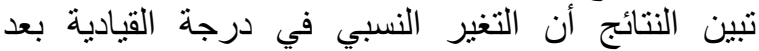

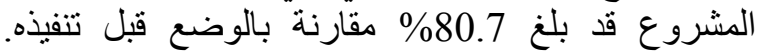

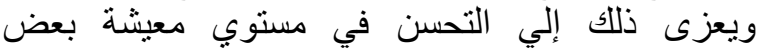

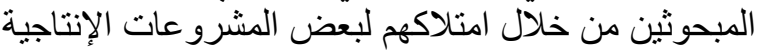

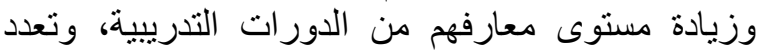

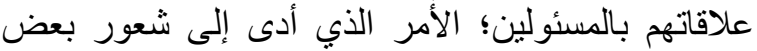

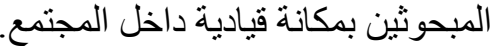

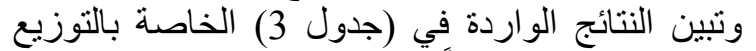

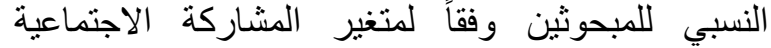

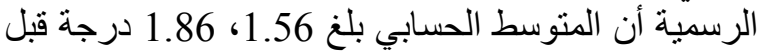
وبعد المشروع علي الترتيب، وبلغت نسبة المبحوثين في

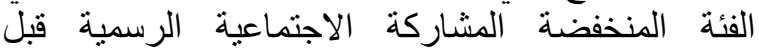

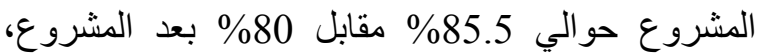
وبلغت نسبة المبحوثين في الفئة المنوسطة قبل المبل المشروع

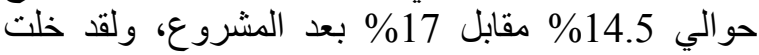

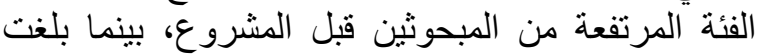

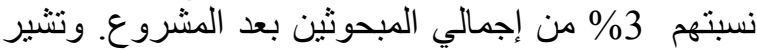

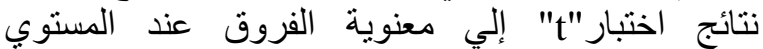

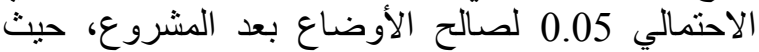

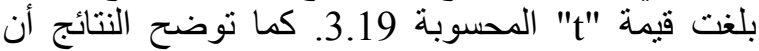

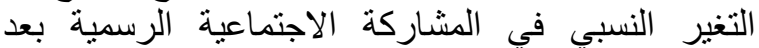

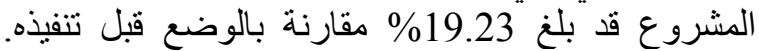

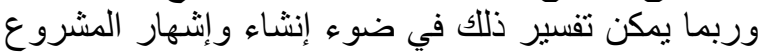

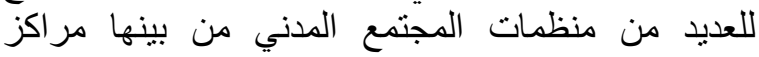

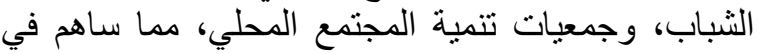

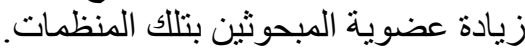

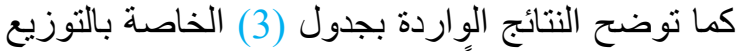

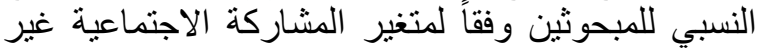

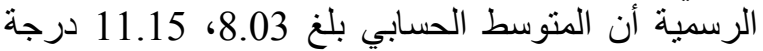

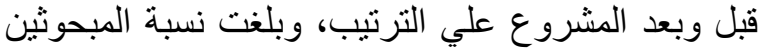

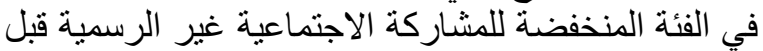

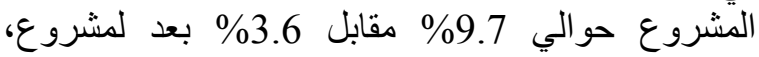

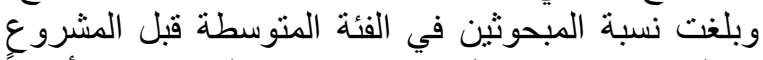
حوالي 78.8\% مقابل 34.5\% بعد فئن المشروع، وأخيراً

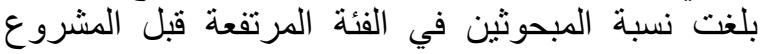
حو الي 11.5\% مقابل 61.8\% من إجمالي المبحوثين بعد

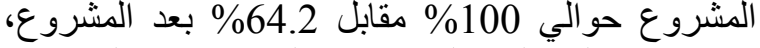

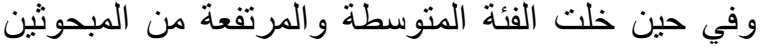

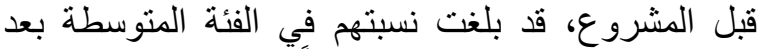

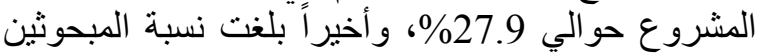

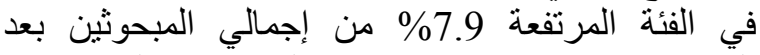

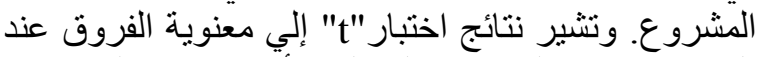

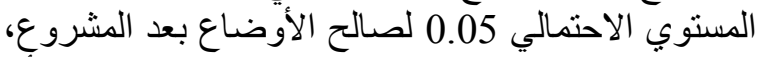

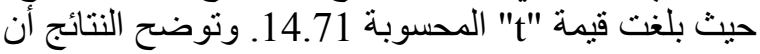
التغير النسبي في درجة الاستفادة من الدورات التونة التدريبية

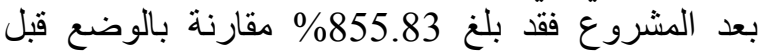

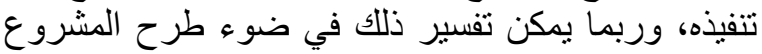

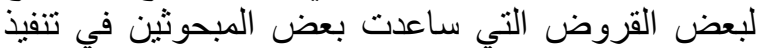
بعض المشروعات الخاصة بالثروة الحيوانية والئية الانتاج النباتي و الميكنة الزر اعية.

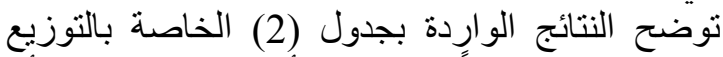

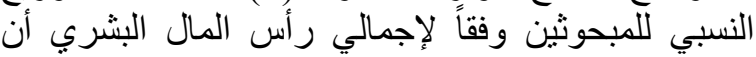

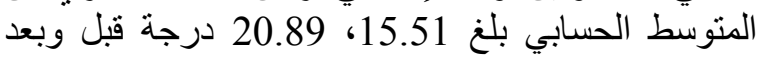
المشروع علي الترتيب، وبلغت المئنة نسبة المبحوثين في الفئة

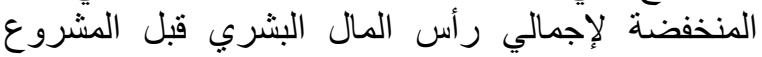

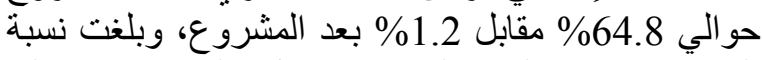

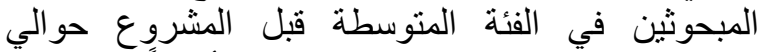

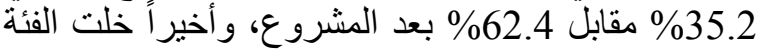

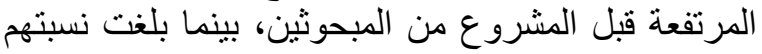

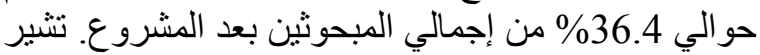

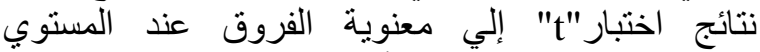

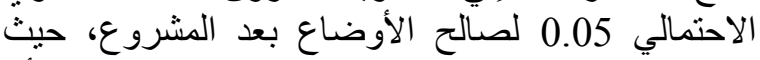

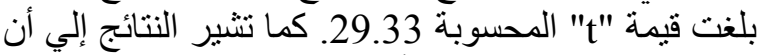

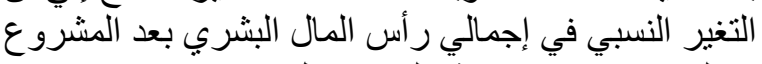

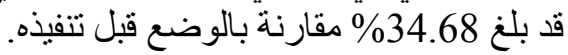

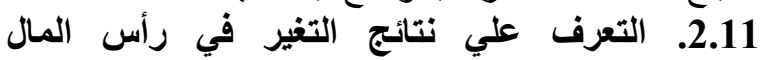
الاجتماعي التجرف

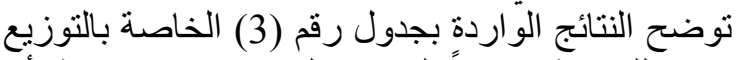

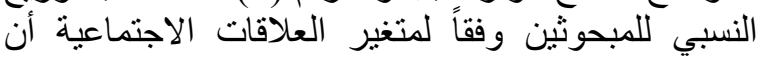
المتوسط الحسابي بلغ ولغ 8.88، 9.9 درجة قبل المبل وبعد المشروع علي الترتيب، لقد تساوت نسبة المبحوثين في

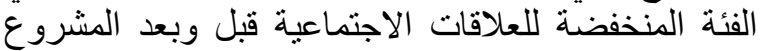

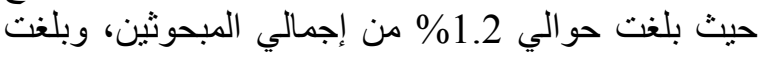

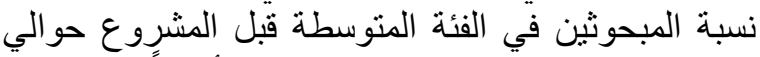

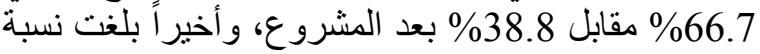

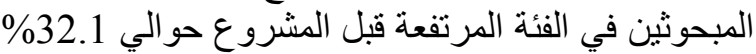
مقابل 60\% من إجمالي المبحوثين بعد المشروع. وتشئ وتشير

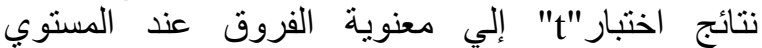

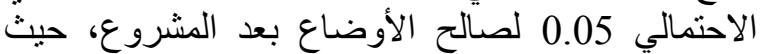
بلغت قيمة "t" المحسوبة 5.4. وتوضئ الأوضح النتائج أن التغير

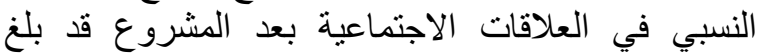

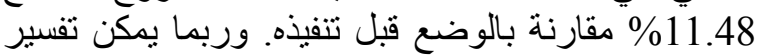

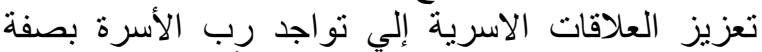

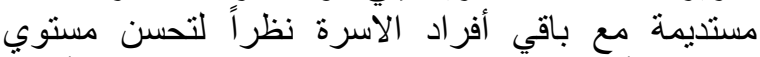
المعيشة، أما بالنسبة لمستوى العلاقات مع الجير ان وأهالي لتهي 
النسبي للمبحوثين وفقاً لمتغير المشاركة السياسية أن

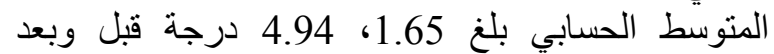
المشروع علي الترتيب، وبلغت نسبة المبحوثين في الفئة

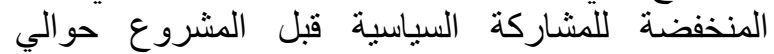

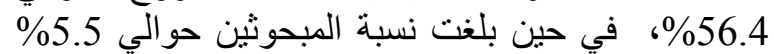
بعد المشروع، وبلغت نسبة المبحوثين في الفئة المتوسطة

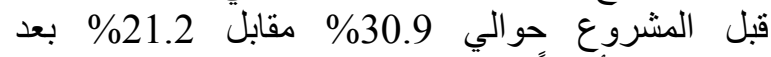
المشروع، وأخير اً بلغت نسبة المبحوثين في الفئة المرتفعة إنة قبل المشروع حو الي 12.1\% مقابل 63.6\% من إلفمالي المبحوثين بعد المشروع.

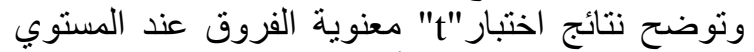

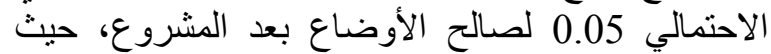

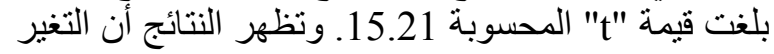

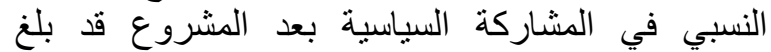
199.39\% مقارنة بالوضع قبل تنفيذه. ويعزى ذلإن للك لقيام

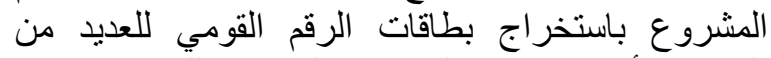

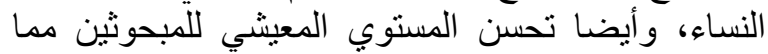
ساهم في إتاحة الوقت للتفكير في الثشئون السياسية.

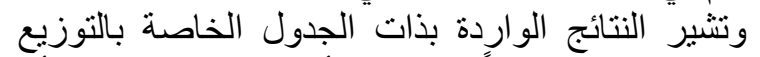

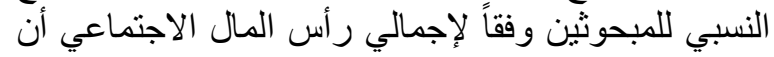
المنوسط الحسابي بلغ 25.24، المشروع علي الترتيب، وبلغت نسبة المبحوثين في الفئة

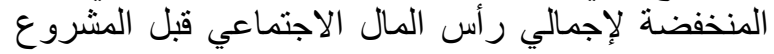

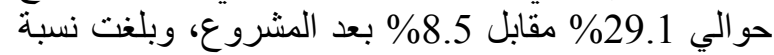
المبحوثين في الفئة المتوسطة قبل المشروع حوالي

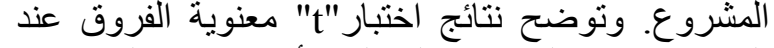

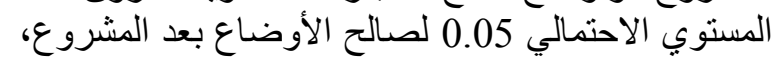

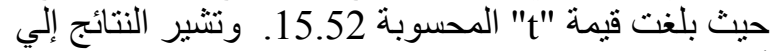
أن التغير النسبي في المشاركة غير الرسمية بعد المشروع

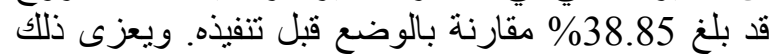

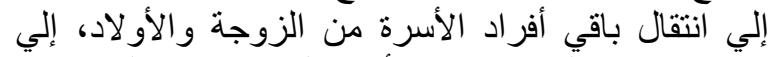

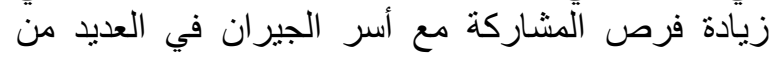

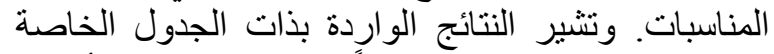

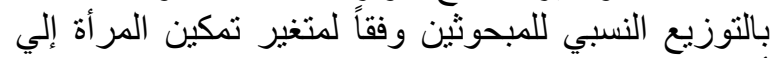

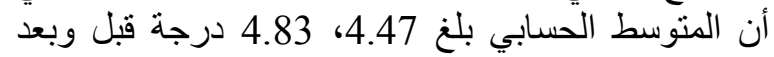
المشروع علي الترتيب، وبلغت نسبة المبحوثين المبن في الفئة المنخفضة لتمكين المرأة قبل المشروع والئرو حوالي 24.8 مقابل 18.8\% بعد المشروع، وبلغت نسبة المبنة المبحوثين في

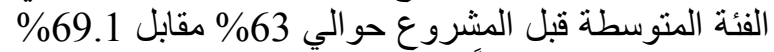
بعد المشروع، وأخيراً تساوت نسبة المبنة المبحوثين في الفئة

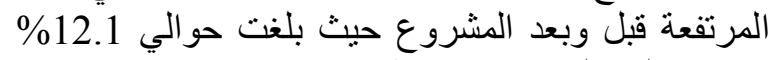

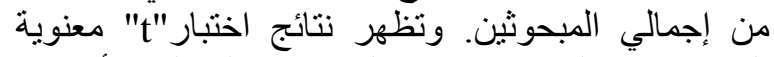

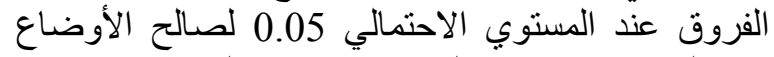

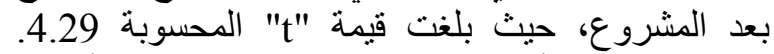

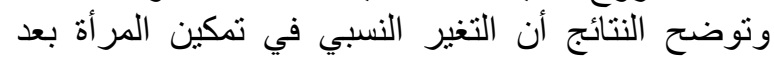

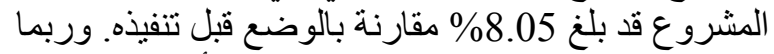

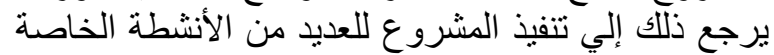

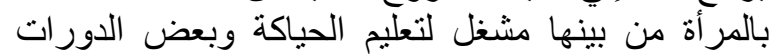
التدريبية لإقامة المشرو عات الصناعات لإنات الغذائية. وتبين من النتائج الواردة بجدول التول (3) الخاصة بالتوزيع

جدول رقم (3): التوزيع النسبي لعينة الدراسة لمحاور رأس المال الاجتماعي.

\begin{tabular}{|c|c|c|c|c|c|c|c|c|c|c|c|c|}
\hline \multirow{3}{*}{ قيمة "tt } & \multicolumn{6}{|c|}{ الفئات } & \multirow{3}{*}{ Std } & \multirow{3}{*}{$\bar{x}$} & \multicolumn{2}{|c|}{ المدي القعلي } & \multirow{3}{*}{ الفترة } & \multirow{3}{*}{ المتغير } \\
\hline & \multicolumn{2}{|c|}{ مرتفعة } & \multicolumn{2}{|c|}{ متوسطة } & \multicolumn{2}{|c|}{ منخفضة } & & & & & & \\
\hline & $\%$ & عدد & $\%$ & عدد & $\%$ & عدد & & & Max & MIIn & & \\
\hline \multirow{2}{*}{$5.40^{*}$} & 32.1 & 53 & 66.7 & 110 & 1.2 & 2 & 1.68 & 8.88 & 12 & 3 & قبل & \multirow{2}{*}{ الاجتماعية } \\
\hline & 60 & 99 & 38.8 & 64 & 1.2 & 2 & 2.02 & 9.90 & 12 & 2 & بعد & \\
\hline \multirow{2}{*}{$14.20^{*}$} & 1.2 & 2 & 44.2 & 73 & 54.5 & 90 & 1.50 & 2.28 & 8 & $\mathbf{0}$ & قبل & \multirow{2}{*}{ درجة القيادية } \\
\hline & 32.1 & 53 & 40.6 & 67 & 27.3 & 45 & 2.24 & 4.12 & 8 & 0 & بعد & \\
\hline \multirow{2}{*}{$3.19^{*}$} & $\mathbf{0}$ & $\mathbf{0}$ & 14.5 & 24 & 85.5 & 141 & 1.34 & 1.56 & 7 & $\mathbf{0}$ & قبل & \multirow{2}{*}{ الاجتماعية المشية } \\
\hline & 3 & 5 & 17 & 28 & 80 & 132 & 1.69 & 1.86 & 10 & $\mathbf{0}$ & بعد & \\
\hline \multirow{2}{*}{$15.52^{*}$} & 11.5 & 19 & 78.8 & 130 & 9.70 & 16 & 2.80 & 8.03 & 15 & $\mathbf{0}$ & قبل & \multirow{2}{*}{ الاجتماعية غير الرسمية } \\
\hline & 61.8 & 102 & 34.5 & 57 & 3.60 & 6 & 3.39 & 11.15 & 15 & 0 & بعد & \\
\hline \multirow{2}{*}{$4.29^{*}$} & 12.1 & 20 & 63 & 104 & 24.8 & 41 & 2.50 & 4.47 & 10 & 0 & قبل & \multirow{2}{*}{ تمكين المرأة } \\
\hline & 12.1 & 20 & 69.1 & 114 & 18.8 & 31 & 2.44 & 4.83 & 10 & $\mathbf{0}$ & بعد & \\
\hline \multirow{2}{*}{$15.93^{*}$} & 1.2 & 2 & 69.7 & 115 & 29.1 & 48 & 5.60 & 25.24 & 39 & 8 & قبل & \multirow{2}{*}{ الاجمالي } \\
\hline & 12.1 & 20 & 79.4 & 131 & 8.5 & 14 & 7.08 & 31.86 & 53 & 11 & بعد & \\
\hline \multirow{2}{*}{$15.21^{*}$} & 12.1 & 20 & 30.9 & 51 & 56.4 & 93 & 2.14 & 1.65 & 6 & 0 & قبل 164 & \multirow{2}{*}{ المياسية:ا(1) } \\
\hline & 63.6 & 105 & 21.2 & 35 & 5.5 & 9 & 1.77 & 4.94 & 6 & $\mathbf{0}$ & $\begin{array}{c}\text { بع } \\
149\end{array}$ & \\
\hline
\end{tabular}


حمد، إسعاف (2015). رأس المال الاجتماعي: مقاربة

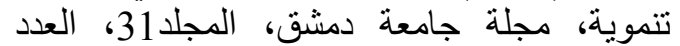
162-139:(3)

دبوس، محمد محمود (32002) (202). تطوير مؤشرات التنمية الريفية، اكاديمية البحث العلمي و التكنولوجيا، كلئ اتلية

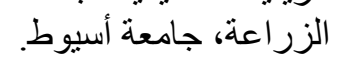

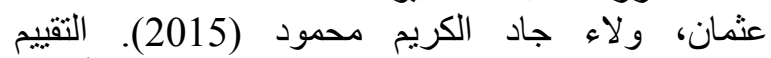
الاجتماعي لبعض مشروعات المات المنظمات الأجنبية

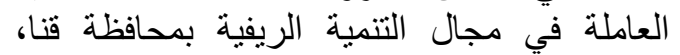

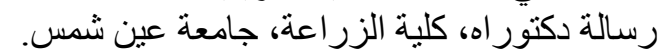

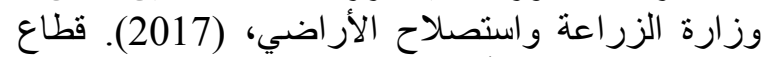

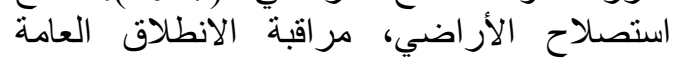

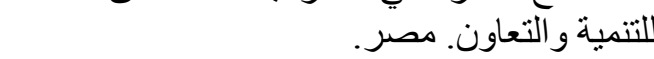
وزارة الزرعة واستصلاح الأراضي، (2015). البيانات

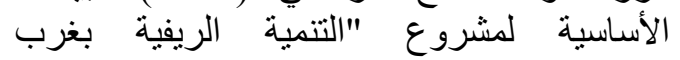

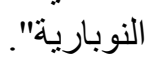

\section{REFERENCES}

Chen H., Zhu T., Krotta M., Calvo J.F., Ganesh S.P., and Makoto I. (2013). Measurement and evaluation of livelihood assets in sustainable forest commons governance. Land Use Policy, 30: 908-914

Colombo E., Romeo F., Mattarolo L., Barbieri J., Morazzo M. (2018). An impact evaluation framework based on sustainable livelihoods for energy development projects: an application to Ethiopia. Energy Research \& Soc. Sci., 39, pp:78-92.

Dabous M. M. M. A. (2000). Toward an Indicator Characterized by Validity for the Measurement of Development, Reinvigorating New Zealand Sociological Association of Aoteroa, Univ. Waikato, Hamilton, NZ.

IFAD (2002) West Noubaria Rural Development Project Appraisal Report, Final version February.

IFAD (2014). West Noubaria Rural Development Project, WNRDP Project Completion Report July.

Mahalaya S. (2010). Impact Evaluation of Agricultural Research in Papua Indonesia Using the Sustainable Livelihood Framework. PH Thesis, School of Agric., Food and Wine, Fac. Scie., Univ. Adelaide., Aust.
69.7\% مقابل 79.4\% بعد المشروع، وأخيراً بلغت نسبة

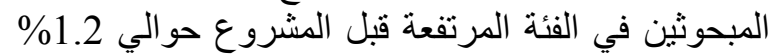

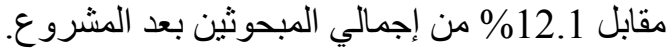

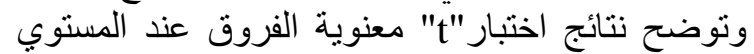

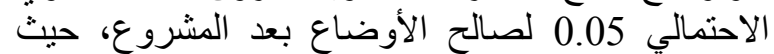

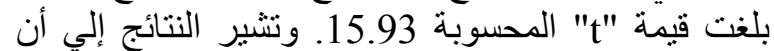

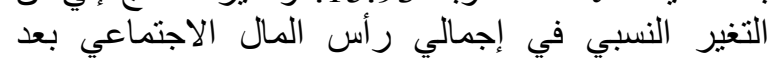
المشروع قد بلغ 26.22\% مقارنة بالوضع قبل تنفيذه.

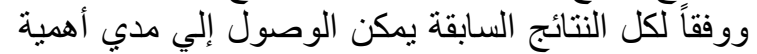

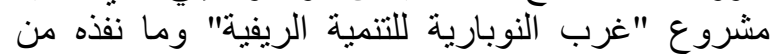

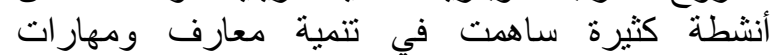

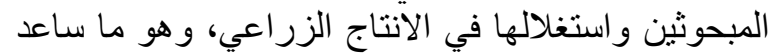
علي استقرارهم حيث عمل علي حل النّاج المشّاكل البيئية مثل

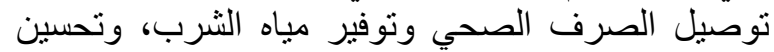

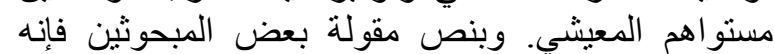

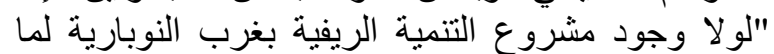

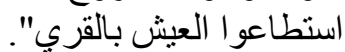

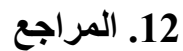

إبراهيم، الخولي سالم، وسليمان حسن الرفاعي، إبراهيم

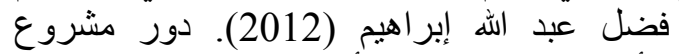
الأسرة في تتمية المرأة المعيلة بريف محافظة البحيرة. مجلة الأزهر للبحوث الزئة الزراعية، العدد .44-25:12

إبراهيمي، نادية (2013). 44. دور الجامعة في تتمية رأس ألمال البشري لتحقيق التنمية المستدامة (دراسة التهة

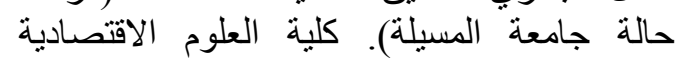

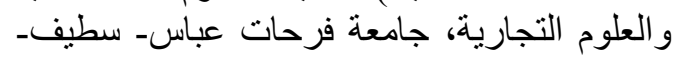

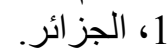

أبو المجد، منال عبد المجيد (2008). محددات جودة الحياة الريفية دراسة لحالة التنمية البشرية بلدية جحافظة أسيوط، رسالة ماجستير، كلية الزراعة، جامعة بهة أسيوط.

الأمم المتحدة، (2015). تحويل عالمنا: خطة التنمية المستدامة لعام (2030). قرار اتخذئه الجمعية العامة في 25 أيلول/سبتمبر (2030).

أمين، إبراهيم رمضان، ومصطفي حمدي أحمد، عبد فيد

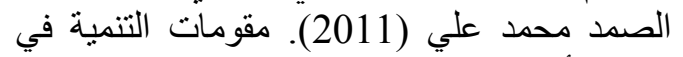

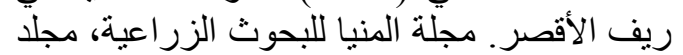

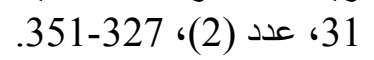

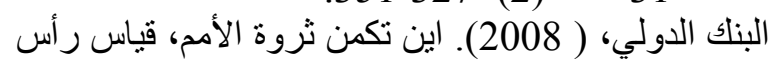
المال للقرن الحادي و العشرين. البنك الدولي، (2011). قِياس مدي نجي لنجاح التدخلات التي

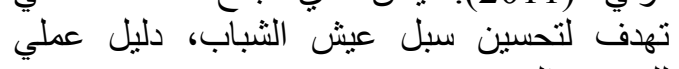
للرصد و التقييم.

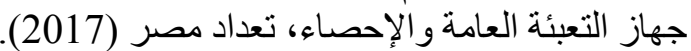

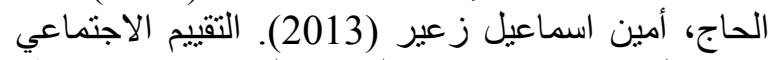

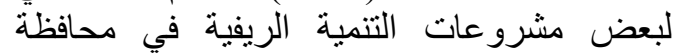

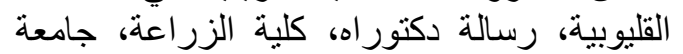

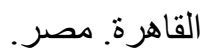

